Nat. Hazards Earth Syst. Sci., 18, 1351-1372, 2018

https://doi.org/10.5194/nhess-18-1351-2018

(C) Author(s) 2018. This work is distributed under

the Creative Commons Attribution 4.0 License.

\title{
Comparison of landslide forecasting services in Piedmont (Italy) and Norway, illustrated by events in late spring 2013
}

\author{
Graziella Devoli $^{1,2}$, Davide Tiranti ${ }^{3}$, Roberto Cremonini ${ }^{3}$, Monica Sund ${ }^{1}$, and Søren Boje ${ }^{1}$ \\ ${ }^{1}$ Department of Hydrology, Norwegian Water Resources and Energy Directorate (NVE), Oslo, 0368, Norway \\ ${ }^{2}$ Department of Geosciences, University of Oslo, Oslo, 0316, Norway \\ ${ }^{3}$ Department of Natural and Environmental Risks, Regional Agency for Environmental Protection of Piedmont (ARPA \\ Piemonte), Turin, 10135, Italy
}

Correspondence: Graziella Devoli (gde@ nve.no)

Received: 16 November 2017 - Discussion started: 27 November 2017

Revised: 9 April 2018 - Accepted: 18 April 2018 - Published: 17 May 2018

\begin{abstract}
Only few countries operate systematically national and regional forecasting services for rainfall-induced landslides (i.e., debris flows, debris avalanches and shallow slides), among them Norway and Italy. In Norway, the Norwegian Water Resources and Energy Directorate (NVE) operates a landslide forecasting service at national level. In Italy, the Regional Agency for Environmental Protection, ARPA Piemonte, is responsible for issuing landslide warnings for the Piedmont region, located in northwestern Italy. A daily hazard assessment is performed, describing both expected awareness level and type of landslide hazard for a selected warning region. Both services provide regular landslide hazard assessments based on a combination of quantitative thresholds and daily rainfall forecasts together with qualitative expert analysis. Daily warning reports are published at http://www.arpa.piemonte.gov.it/rischinaturali and www.varsom.no, last access: 7 May 2018.

In spring 2013, ARPA Piemonte and the NVE issued warnings for hydro-meteorological hazards due to the arrival of a deep and large low-pressure system, called herein " $\mathrm{Vb}$ cyclone". This kind of weather system is known to produce the largest floods in Europe. Less known is that this weather pattern can trigger landslides as well.

In this study, we present the experiences of NVE and ARPA Piemonte in the late spring of 2013. The Vb cyclone influenced weather throughout Europe over a long period, from the end of April until the beginning of June 2013. However, major affects were observed in the first half part of this period in Piedmont, while in Norway, major damage was reported from 15 May to 2 June 2013. Floods and landslides
\end{abstract}

significantly damaged roads, railways, buildings and other infrastructure in both countries.

This case study shows that large synoptic pattern can produce different natural hazards in different parts of Europe, from sandstorms at low latitudes, to flood and landslides when the system moves across the mountain regions. These secondary effects were effectively forecasted by the two landslide warning services, operating in different parts of Europe. The landslide risks were also properly communicated to the public some days in advance. This analysis has allowed the establishment of fruitful international collaboration between ARPA Piemonte and NVE and the future exchange of experiences, procedures and methods relating to similar events.

\section{Introduction}

One of the targets proposed by the Sendai Framework (UN, 2015 ) is to substantially increase the availability of access to multi-hazard early warning systems and disaster risk information to the public by 2030 (UN, 2015). It also emphasizes the need for enhancing preparedness, response, recovery, rehabilitation and reconstruction in order to reduce natural disaster risk and that response actions must be focused within and across sectors, by states, at local, national, regional and global level.

UNISDR (2009) defined an early warning system (EWS) as "a set of capacities needed to generate and disseminate timely and meaningful warning information to enable indi- 
vidual, communities and organizations threatened by a hazard to act appropriately and in sufficient time to reduce the possibility of harm or loss". To be efficient, EWSs should include four elements: knowledge of the physical mechanisms that cause the hazard and the exposed elements at risk; the technical capacity to continuously monitor the hazard and to develop changing scenarios to issue warnings; the communication of the warning and the capacity to translate the prediction into warning and action plans (Cloutier et al., 2015). Worldwide there are many EWSs currently operated for various types of natural hazards, including landslides.

Landslides are a serious hazard in many countries, causing significant loss of lives yearly (Petley, 2012; Haque et al., 2016) and large damage to infrastructure. Landslides are defined as "the movements of a mass of rock, debris or earth down a slope" (Cruden and Varnes, 1996) and are classified based on the failure mechanisms and the type of material (Hungr et al., 2014). However, other parameters like rate of movement (e.g., velocity) and the size and depth of sliding surface, among others, can be used to classify them. Using velocity as a criteria, the so-called "rapid landslides" are those with velocity $>1.8 \mathrm{~m} \mathrm{~h}^{-1}$, and "extremely rapid" are those with velocity larger than $5 \mathrm{~m} \mathrm{~s}^{-1}$ (Cruden and Varnes, 1996). It is sometime useful to classify landslides based on type of triggering factors, thus expressions like "earthquake-induced landslides", "rainfall-induced landslides", "precipitation-induced landslides", "weatherinduced landslides" and "snowmelt-induced landslides" are often used in literature (Baum and Godt, 2010; Calvello, 2017; Katsura et al., 2008; Rodríguez et al., 1999; Havenith et al., 2016). The landslides triggered by short- or longduration intense rainfall are in general called rainfall-induced landslides or precipitation-induced landslides, while if abundant snowmelt is causing them, snowmelt-induced landslides is often used. The expressions weather-induced, rainfallinduced and snowmelt-induced landslides have been used as general terms to include both landslides triggered by rainfall and/or by snowmelt, especially in mountainous areas covered by snow, where they can occur simultaneously especially during spring.

The landslide types triggered by rainfall and snowmelt episodes are usually in the category of slide- and flow-type landslides (Hungr et al., 2014). The following types are commonly observed:

a. Soil slides (e.g., clay/silt planar slides) and debris slides (e.g., gravel/sand/debris slides) are usually of small size (volume inferior to $5000 \mathrm{~m}^{3}$ ), and are shallow slides with a sliding surface of 1-2 $\mathrm{m}$ deep that occur within the soil material or at contact with the underlying less permeable bedrock (as also observed by Zêzere et al., 2015). They are planar slides; however, a few rotational ones may occur, especially in clay/silted soils.

b. Debris avalanches occur often in open slopes, initiating as shallow planar soil or debris slides. c. Debris flows and debris floods occur usually in steep channels, starting as stream bed erosion or from soil slides, debris slides or debris avalanches from a steep bank, entraining material downslope.

See Hungr et al. (2014) for more details.

These main types of soil slip develop in steep slopes and are characterized by high rate of movement, varying from rapid to extremely rapid events. They occur in different types of soil: residual soils, colluvial, pyroclastic, fluvial and tills deposits or organic soils. Near infrastructure and buildings soil slides may occur in artificial loose fills. They are triggered by short duration rainfall events (minutes to hours), due to rapid infiltration and percolation of water in the thin soil material.

Debris flows are known to be the most destructive ones, because of their high velocity and long run-outs; debris avalanches are also quite destructive as they usually occur in clusters and due to their potential to spread out in the depositional area. Soil and debris slides, even if relatively shallow and of small size, occur in clusters, causing significant damage to infrastructure and even loss of life if they occur close to inhabited areas. They occur over a large area all at the same time and often simultaneously with floods making damage much more extensive.

The occurrence of these types of landslides has become more frequent and, as population and infrastructure have increasingly expanded into landslide-prone areas, their impacts on society have become more dramatic. Recent studies shows that these could be potentially enhanced under a changing climate (Stoffel et al., 2014; Gariano and Guzzetti, 2016 and reference therein).

Effective landslide warnings have become essential elements of integral risk management worldwide, since they are a cost-effective risk mitigation measure and in some regions the only suitable option for a sustainable landslide risk management (Glade and Nadim, 2014). EWSs for landslides are designed to detect events that precede a landslide in time to issue an imminent hazard warning (Di Biagio and Kjekstad, 2007) and initiate actions to mitigate and to reduce the potential damage and allow people to get to safety.

The development of landslide EWSs has not been uniform worldwide, and a few public resources have been invested in the past for their establishment, probably because the landslides losses are perceived as private economic losses, like in USA (Baum and Godt, 2010). Apart from the case of Hong Kong, where the first landslide EWS was organized in 1977 and is still operative (Chan et al., 2003), in other countries, it was at the end of the 1990s that most of the EWSs started to be developed (D'Orsi et al., 1997). In the 1980s, in USA, there were two attempts of EWSs. The first recorded debris flow early warning attempt was done in the spring of 1984 in the state of Utah, while in the San Francisco Bay Area of California the first experimental operating landslide EWS started in 1985, but a decade later both were closed, because of a 
shortage of personnel and lack of adequate funding (Baum and Godt, 2010).

EWSs are technical feasible for some types of landslides. Overview and classification of existing landslide EWSs are presented in Thiebes et al. (2012), Bazin (2012) and later Stähli et al. (2015). The latter authors have proposed an overview and a classification of existing early warning systems for rapid mass movements (e.g., debris flows and snow avalanches) where three main categories are identified: (i) alarm, (ii) warning and (iii) forecasting. Another recent summary of existing weather-induced landslide EWSs is presented in Calvello (2017) in which systems are differentiated as local and territorial. The literature shows that many local early warning systems exist at specific sites, for rockslides, deep-seated complex landslides and debris flows where extensive monitoring instrumentation provides detailed information (i.e., Bardoux et al., 2009; Blikra et al., 2013; Michoud et al., 2013 and references therein). The territorial EWSs have acquired importance in the last 15-20 years and especially after the Hyogo Framework for Action (20052015), adopted by the World Conference on Disaster Reduction (UNISDR, 2005). They are mainly constrained to forecast the occurrence of rainfall-induced landslides (i.e., Osanai et al., 2010; Baum and Godt, 2010; Jakob et al., 2012; Liao et al., 2010; Pumo et al., 2015; Segoni et al., 2014; Lagomarsino et al., 2013; Tiranti and Rabuffetti, 2010; Ponziani et al., 2013; Huang and Hong, 2010).

Many countries have spent recent decades working on preparing the technical basis for early warnings, by understanding landslide initiation, defining rainfall thresholds, installing real-time monitoring instruments and organize prototypes of landslide warning systems, but a few of them became operational. In agreement with other authors (Segoni et al., 2015) in general the potential of EWSs is not yet fully exploited by governments and decision-makers.

A broad range of literature exists on the definition of empirical rainfall thresholds for the possible landslide initiation or description of single components of the system (Segoni et al., 2018 and references therein). The thresholds may define the rainfall, soil moisture or hydrological conditions that, when reached or exceeded, are likely to trigger landslides. Therefore, successful prediction of landslide hazards in large regions greatly depends on ability to link meteorological conditions with various types and extents of slope failures. In the prevention of rainfall- and snowmelt-induced landslides at territorial level, the recognition of the relationship between large-scale patterns and landslides occurrence is important to investigate. The synoptic weather and landslides occurrence has been demonstrated in a few works. Large-scale pattern phenomena such as El Niño and the North Atlantic Oscillation (NAO) change slowly and impact both precipitation regime and temporal occurrence of different landslide types in different areas of the world have been demonstrated. In 2005, Trigo et al. (2005) found connections between the NAO index and the occurrence of landslides in Portugal.
Wood et al. (2016) investigated the synoptic weather trends and landslide in the European Alps. The meteorological control on the distribution of debris flows in Iceland was also investigated by Decaulne and Sæmundsson (2007). Large synoptic weather events were investigated in southern Norway (Devoli et al., 2017). Understanding the relationships of weather, climate, precipitation and landslide occurrence will allow the prediction of certain types of weather development and allow states and the public to be better prepared.

Literature shows that few examples describe how warning systems work, what their performances are or how they are received by the public or other stakeholders. The comparison of different EWSs and specifically their operation is even rarer and a quite unexplored topic. To our knowledge a few have been made (e.g., Baum and Godt, 2010; Lagomarsino et al., 2015; Zêzere et al., 2015) but they mainly compare some technical components, like the application and performance evaluation of different thresholds in the same area. The various EWSs consist of different components, and therefore it is important to analyze not only the performance of the single components, but the performance of the entire system. However, components like expert knowledge decision are difficult to judge in objective way and there are no methods in place. The lack of comparison among existing EWSs is also due to the fact that many EWSs are still not fully operative or they have recently started operation, and therefore lack data for analysis.

Norway and Italy have a long tradition of flood forecasting, but only in (relatively) recent years have efforts been made to design, develop and operate landslide forecasting services, often in synergy with flood and/or snow avalanche forecasting. The Norwegian Water Resources and Energy Directorate (NVE) operates a landslide forecasting and warning service at national level (in Norwegian Jordskredvarsling) since 2013. The service is relatively new. Since its beginning, its focus has been on its design and implementation at the national level, not describing its function to an international audience. The emphasis has been on the establishment and training of forecasters, on the development of existing web tools used for flood and snow avalanche forecasting to include landslide-related parameters and thresholds, and on the establishment of routines, implementation and updating landslide thresholds and definition of warning and performance evaluation criteria (Colleuille et al., 2017; Devoli et al., 2014; Boje et al., 2014). The performance of the service was recently tested using the event, duration, matrix performance (EduMaP) method in Piciullo et al. (2017) and the description of the entire service is given in (Krøgli et al., 2017).

In Italy the landslide hazard assessment is not national but regional. In Piedmont the regional environmental agency (Regional Agency for Environmental Protection, ARPA) is responsible for the daily landslide hazard assessments and emission of landslide warnings and operated the local EWS since 2008 (Tiranti and Rabuffetti, 2010). 

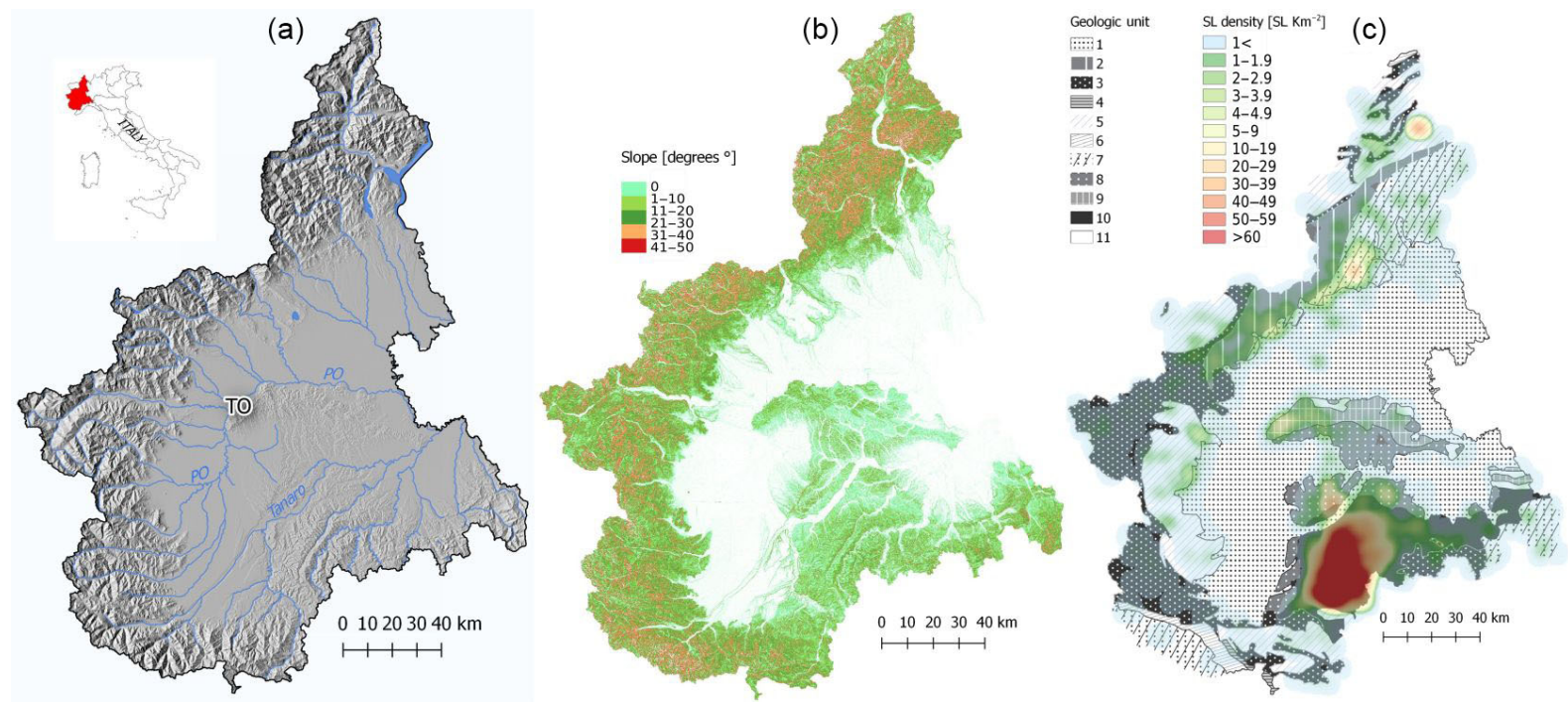

Figure 1. (a) Physiography of Piedmont, TO stands for Turin; (b) slope distribution of Piedmont; (c) density distribution of shallow landslides (from 1962 to 2016) compared with the geological/structural sketch map of Piedmont: (1) Quaternary; ALPS: (2) Austroalpine domain (pre-Alpine crystalline basement and Palaeozoic cover); (3) Penninic domain (Permian-Mesozoic-Tertiary metamorphic cover; (4) Penninic domain (Helminthoid flysch units); (5) Penninic domain (pre-Triassic crystalline basement); (6) Helvetic domain (Permian-Mesozoic cover); (7) Helvetic domain (pre-Alpine crystalline basement and Carboniferous cover); APENNINE and HILLS: (8) internal margin foredeep deposits; (9) epi-Ligurian sequences (epi-sutural basins deposits unconformably covering the Ligurian units); (10) epi-Ligurian sequences (Oligo-Miocene of Langhe); (11) Ligurian and sub-Ligurian units (nappes, locally ophiolitic bearing); (a) Front of tectonic units (limits of different paleogeographic domains); (b) Neotectonic deformation zones.

In this study, we compare two examples of forecast and warning services for rainfall and snowmelt-induced landslides successfully operating in Piedmont, northwestern Italy, and in Norway. The main objective of this study is to shows how the two services are organized, but also how they operated and performed under the same large synoptic pattern that hit Europe in 2013.

Another important objective of this work is to demonstrate that the weather synoptic systems, known as $\mathrm{Vb}$ cyclones, are often responsible for intense rainfall events and associated with high temperatures producing intense snowmelt in many European countries, triggering not only large floods but also many landslides. Quite often forecasting services focus on the analysis of the climatic and meteorological conditions in their own region, forgetting that the rainfall can be part of larger processes and landslide can occur across multiple municipalities, regions and even countries at the same time. An example is the landslides triggered by Hurricane Mitch in 1998 across Central America (i.e., Bucknam et al., 2001; Cannon et al., 2002) or the landslides triggered by the storm Desmond on 4 and 5 December 2015 in the UK and Norway. The study aims to demonstrate that cooperation between countries and between operational landslide warnings is necessary and the increased knowledge of weather system patterns and shared experiences can enhance forecast leading time and improve daily landslide hazard assessment.

\section{Study areas}

Although the two areas are located at different latitudes, both are characterized by complex orography and similar geological surficial processes. Moreover, according to Peel et al. (2007), both the Norwegian mountains (Nordryggen) and the Italian Alps belong to the same Köppen-Geiger climate class.

\subsection{Piedmont region, Italy}

The Piedmont region is complex from a geomorphological and geological point of view. Its territory is shaped by mountain environments (western Alps and subordinate Apennine with peaks ranging from 1000 to $4800 \mathrm{~m}$ a.s.1.), hills (Torino hill, Monferrato hills and Langhe with an elevation range of 400-700 m a.s.1.), and alluvial plains (200$300 \mathrm{~m}$ a.s.l.), surrounded by the Alps and Apennines on three sides (Fig. 1a). The western Alps are characterized by a complex double-verging structure with asymmetrical transversal cross-section (Roure et al., 1990, 1996; Pfiffner et al., 1997), subdivided into three main structural sectors. (1) SouthAlpine domain characterizes the internal sector (the collisional system upper plate consists in Hercynian and preHercynian bedrock formed by lower continental and upper mantle rocks). (2) Helvetic-Dauphinois domains constitute the external sector, representing the European foreland zone, formed by Hercynian intrusive massifs system and Meso- 
zoic flysch cover. (3) Frontal thrust of Penninic domain and the Insubric front (Malusa and Vezzoli, 2006) bound the axial sector formed by Hercynian and pre-Hercynian continental rocks and Hercynian metasedimentary formations, oceanic lithosphere rocks and ocean fronting continental boundaries and orogenic flysch units. During the Quaternary, wide glaciers occupied Alpine valleys and were molded by glacial pulsations. Locally, glacial landforms and deposits were modified by Holocene fluvial/torrential processes associated with widespread landslides (Soldati et al., 2006).

The geology of hilly environment is mainly formed by Oligo-Miocene sedimentary strata, originated during the Tertiary Piedmont Basin where the lowest term of sedimentary sequence is formed by shallow-sea deposits, while deep marine environment (turbidite deposits up to $4 \mathrm{~km}$ thickness) represents the upper part of the sedimentary sequence. The stratigraphic succession is due to Oligocene marine transgression made by the alternation of marls, sandstones and shales (about $5-50 \mathrm{~cm}$ thickness); strata dipping NW with $8-15^{\circ}$ inclination. Sin-sedimentary tectonics controlled the thickness and lateral interdigitations of the stratigraphic successions. The northward movement of the Padan thrust belt (Falletti et al., 1995) caused the progressive uplifting of the basin which has occurred since the Langhian. The sedimentary sequence lies on Alpine metamorphic units by unconformity (Biella et al., 1987, 1992; Gelati and Gnaccolini, 1988). Apennine units are poorly represented within the borders of Piedmont, mainly represented by Ligurian, sub-Ligurian and epi-Ligurian units (Fig. 1b).

As shown in Fig. 1c, the main occurrence of shallow landslides (density interpolation map of 33000 shallow landslides occurred from 1962 to 2016) corresponds with the epiLigurian sequences (Oligo-Miocene of Langhe: hilly environment), the Helvetic domain (pre-Alpine crystalline basement and Carboniferous cover: northwestern Alps), the Penninic domain (pre-Triassic crystalline basement: northern Alps), the internal margin foredeep deposits (hilly environment) and the epi-Ligurian sequences (epi-sutural basins deposits unconformably covering the Ligurian units: Torino hill).

The spatial distribution of annual rainfall shows high precipitation in the northern areas with more than $2100 \mathrm{~mm}$ year $^{-1}$, and low precipitation in the eastern part of the plains with less than $700 \mathrm{~mm}$ year $^{-1}$ (Fig. 2). The monthly distribution of precipitation in Piedmont shows a bimodal distribution, with two peaks during spring and fall, and two minimums during winter and summer. Four rainfall regimes (three continental and one Mediterranean) can be differentiated:

- pre-Alpine: dry season during winter, main maximum during spring and secondary maximum during fall;

- sub-coastal: dry season during summer, main maximum during fall and a secondary maximum during spring;

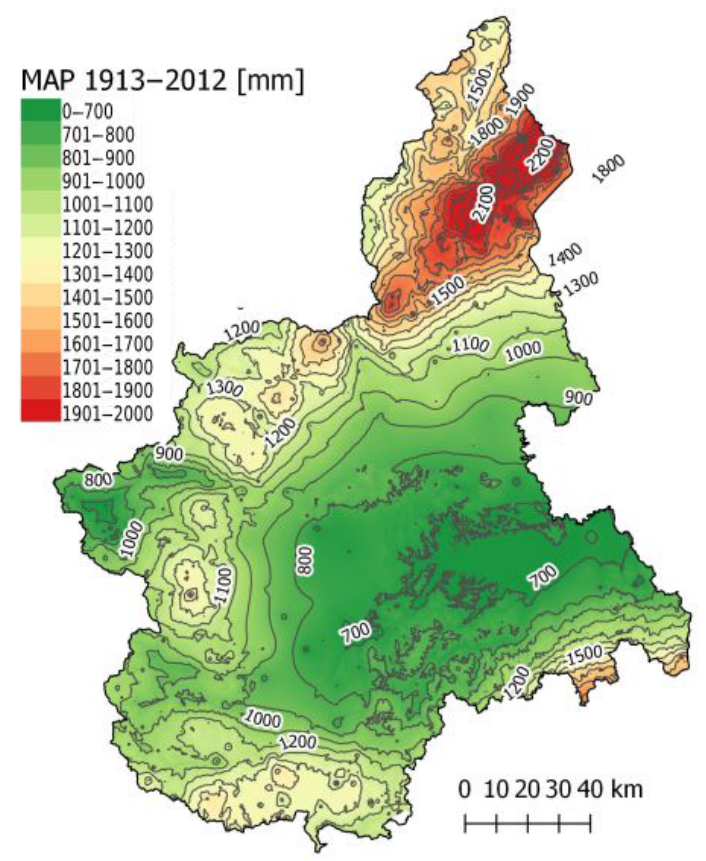

Figure 2. Mean annual precipitation (MAP) in Piedmont from 1913 to 2012 (source: ARPA Piemonte).

- sub-Alpine: dry season during winter, main maximum during fall and secondary maximum during spring;

- sub-continental: dry season during winter, main maximum during fall and a secondary maximum during summer.

\section{2 Østlandet region, Norway}

The region Østlandet in southeastern Norway also has a complex geomorphological and geological setting. The region includes eight administrative counties. The highest mountains are in the northern and western part of the area with maximum elevations up to $2469 \mathrm{~m}$ a.s.l., observed in the Jotunheimen area. The region is mostly hilly, with dominant landforms represented by glacially scoured valleys directed N$\mathrm{S}$ in the eastern sector, facing NW-SE in the western sector, congregating around the Oslofjord (Fig. 3a). The valleys Østerdalen and Gudbrandsdalen are the longest in the country. The region contains also some very large areas of lowland surrounding the Oslofjord. The longest river and watercourses, Glomma, and the biggest lake, Mjøsa, are also located in this region. Southeastern Norway contains extensive areas with forest and rich arable land. From a geological point of view, this region is dominated by bedrock of the Baltic shield, characterized by Precambrian basement rocks (e.g., granites, granodiorite, gneisses, amphibolites, rhyolite, gabbro, diorite and meta-sediments). In the northern sector rocks within the Caledonian orogen (e.g., sandstone, schist, amphibolite, mica schist, phyllite conglomer- 

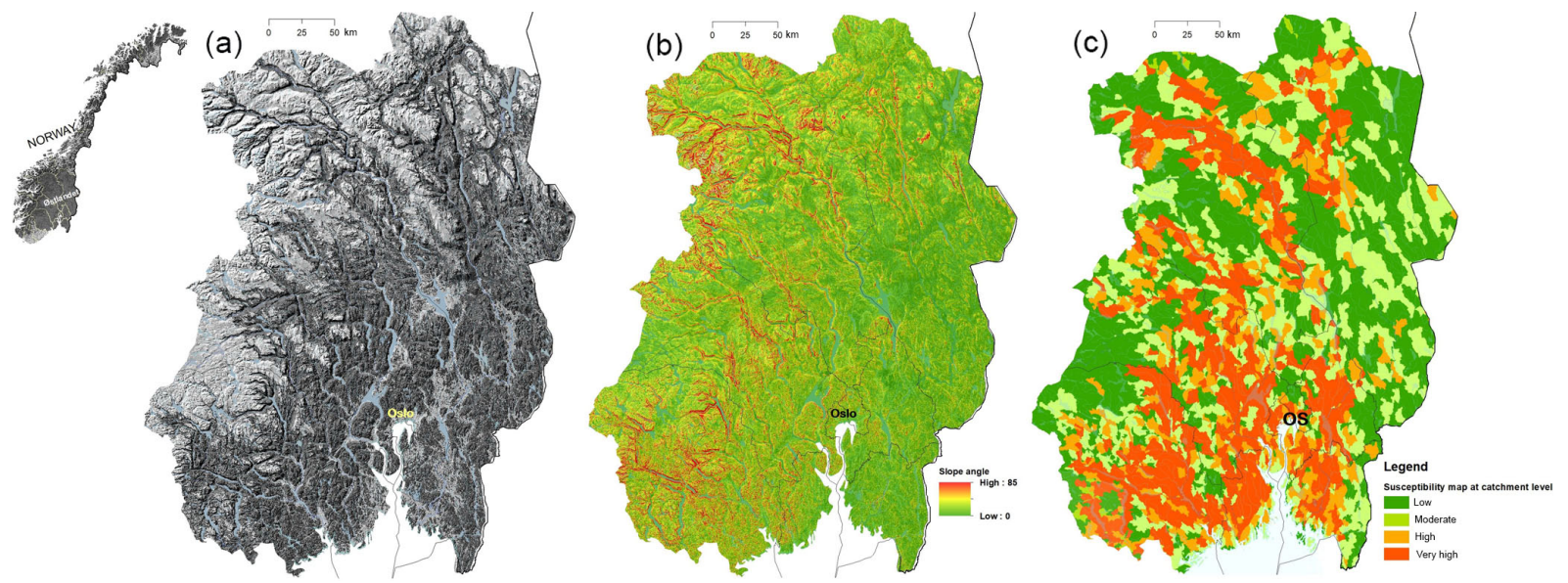

Figure 3. Østlandet region: (a) physiography; (b) slope distribution; (c) landslide susceptibility map (unit: first-order catchment).

ate) prevail. Cambro-Silurian sedimentary rocks (e.g., shale, limestone and phyllite) and Permian volcanic rocks (syenite, granite monzonite, porphyritic rocks and basalt) occur within the Oslo Graben (Solli and Nordgulen, 2006). Quaternary deposits that cover the bedrock are mainly left by glacial processes. Continuous till deposits cover large areas of the hilly mountains and valley sides and floors, with a variable thickness from 0.5 to a couple of meters. The bottom of the valleys is mainly covered by thick fluvial and glaciofluvial deposits. Till deposits have a large heterogeneity in terms of granulometry and composition. The amount and the composition varies as function of the bedrock, in some places the till deposits are covered by landslide deposits, which occurred after glaciation. Marine clay deposits are observed in the southern sector of the region.

Most of the rainfall-induced landslides in the region occur in proximity of steep slopes, (Fig. 3b) covered by till deposits, especially where there is a large clay mineral content that reduces the water infiltration and provides more surficial runoff. The red areas in Fig. 3c, show where landslides susceptibility is high in the region. Two sectors are most prone to landslides: the steep slopes of glacially scoured valleys oriented N-S and NW-SE, covered by till deposits, where mainly debris flows and debris avalanches are observed, and the southern sector, where marine clay deposits are prevalent. Here clay slides and quick clays slides may form, the latter triggered mainly by human activities.

Based on Köppen classification, the climate of the region varies from a tundra type (ET) in the northwestern part, to subarctic (Dfc) in the central part. The warm summer humid continental type $(\mathrm{Dfb})$ and oceanic type $(\mathrm{Cfb})$ are mainly observed in the southern sector and along the southern coastline. In this region, the climate is mainly characterized by cold winter and warm summer. The amount of precipitation in form of rainfall and snow varies depending on the area (i.e., valley floor and mountain), but in general this area is the driest of Norway with low precipitation, mostly during sum-

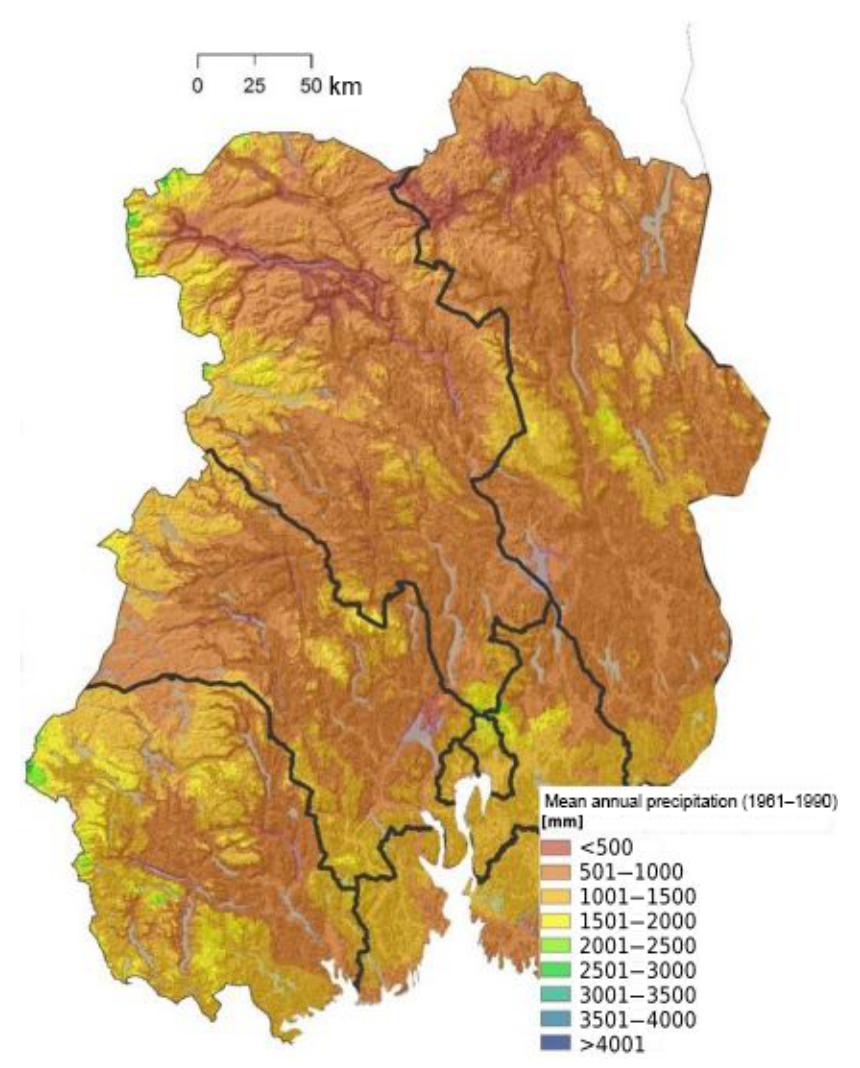

Figure 4. Mean Annual Precipitation (MAP) of Østlandet region.

mer. Deficits of precipitation are observed at Skjåk where the annual precipitation is of about $317 \mathrm{~mm}$ (water equivalent) or Biri with $754 \mathrm{~mm}$ annual precipitation. The area has a normally stable snow cover during winter, with normal annual maximum (1971-2000) around $1000 \mathrm{~mm}$ in the mountains (Fig. 4). The annual medium temperature ranges from $-7^{\circ} \mathrm{C}$ in the mountain area to $7^{\circ} \mathrm{C}$ in the coastal area. 


\section{The landslide forecasting services in Piedmont region and in Norway}

The warning services herein presented are classified as "territorial" (Calvello, 2017) and they can be classified as both "forecasting-type" and "warning-type" services (Stähli et al., 2015) because they predict the level of danger, and the occurrence of multiple landslides over a warning area and at regular intervals (e.g., daily), but also because data interpretation and the initial alert are based on predefined thresholds. Experts consult prediction models, thresholds and analyze observations to forecast the regional danger levels, which are communicated widely in a bulletin. The main goal of these services is to save lives, to reduce landslide risks for roads, railways and settlements, and also increase safety and predictability. In addition, to contribute to a better foundation for emergency preparedness at local level, services provide continuous information on conditions and expected development to national and regional authorities and the public.

As stated in Sect. 1, both the services are designed to forecast the occurrence of rainfall- and snowmelt-induced landslides, i.e., shallow landslides and debris slides, debris avalanches and debris flows (Hungr et al., 2014); the Norwegian landslide forecasting and warning service is also responsible for slush-flow warning. Table 1 summarizes the main characteristics of the services herein described, showing similarities and differences.

\subsection{Piedmont's landslide forecasting service}

The Regional Warning System for Geo-Hydrological hazards of ARPA Piemonte includes three independent early warning systems (EWSs), based on empirical rainfall thresholds and designed ad hoc for different typology slope processes, whose triggering is generally determined by precipitation with different intensity over different durations:

- DEFENSE (DEbris Flows triggEred by storms - Nowcasting SystEm) is operated to forecast the occurrence of channelized debris flows in small Alpine catchments. DEFENSE works by the combination of the GIS environment of different Alpine catchments, classified by the clay weathering index, and instantaneous rainfall intensity $\left(\mathrm{mm} \mathrm{h}^{-1}\right)$, provided by the weather radar using a storm-tracking algorithm (Tiranti et al., 2014). The use of quantitative precipitation estimates (QPEs) by the Cband weather radar is limited to Alpine areas where the radar visibility is good and uncertainties limited. More details on the operational weather radar operated by ARPA Piemonte can be found in Davini et al. (2011); Cremonini and Bechini (2010).

- SMART (Shallow landslides Movements Announced through Rainfall Thresholds) is operated to forecast shallow landslides in mountain area (zone 1) and hilly environments (zone 2). Threshold equations in the two zones are

$I=25 \cdot D^{-0.45}$ Zone 1 ,

$I=40 \cdot D^{-0.65}$ Zone 2 ,

where $I$ is the rainfall mean intensity $\left(\mathrm{mm} \mathrm{h}^{-1}\right)$ and $D$ is the rainfall duration (h). More details are reported in Tiranti and Rabuffetti (2010).

- TRAPS (Translational/Rotational slides Activation Prediction System) is operated to forecast deep-seated translational and rotational slides in the hilly environment. TRAPS analyzes 60 days of antecedent precipitation, including water from snowmelt (Tiranti et al., 2013).

ARPA Piemonte daily evaluates the EWS responses to issue a regional warning to civil protection units, municipalities and citizens regarding the occurrence of slope processes. All the EWSs responses are displayed and managed through a WebGIS interface (Fig. 5) that allows a real-time estimation of hazard scenarios induced by observed and/or forecasted weather conditions. All the Piedmont EWSs operate continuously and automatic warnings are issued by e-mail and SMS to experts.

\subsection{The Norwegian landslide forecasting and warning service}

The landslide assessment is done by a forecaster, who consults weather forecasts, landslides thresholds and other relevant hydro-meteorological parameters daily. This information is available as raster data with $1 \mathrm{~km}^{2}$ resolution and presented as thematic maps at http://xgeo.no, last access: 7 May 2018, a portal that assist experts in the daily forecasting of floods, snow avalanches and landslides (Krøgli et al., 2017). Here, weather prognoses, forecasted thresholds and hydro-meteorological parameters are published daily for the following 6 days. The portal also visualized past interpolated weather observations, thresholds and others parameters. Besides the thematic maps, the forecaster on duty may need to consult real-time hydro-meteorological observations, in particular groundwater level or water discharge values at specific stations within the possible warning area. These data are also available at the same website: http://xgeo.no.

The weather prognosis, temperature and precipitation are obtained from AROME MetCoOp model (used in the Scandinavian regions as a short-term forecast model for the first 3 days) and EC model (a global long-term European model, for the following 3 days). The models operate in 24 and $3 \mathrm{~h}$ resolution. Temperature and precipitation are also used as input variables in two hydrological models (Krøgli et al., 2017). The main model is a distributed version of the conceptual HBV model (Beldring et al., 2003) that divides the country into grid cells, each one modeled as a separate basin 
Table 1. Characteristics of the EWS from ARPA Piemonte and Norway.

\begin{tabular}{|c|c|c|}
\hline EWS & Piedmont, Italy & Norway \\
\hline Operators & ARPA Piemonte (Regional government) & NVE (National government) \\
\hline Activated & 2008 & 2013 \\
\hline Status & operative (daily) & operative (daily) \\
\hline Landslide types & $\begin{array}{l}\text { shallow translational slide; channelized debris } \\
\text { flow; rotational slide }\end{array}$ & $\begin{array}{l}\text { shallow translational slide; channelized debris flow; } \\
\text { debris avalanches; slush flows }\end{array}$ \\
\hline Type of triggering & rainfall and snowmelt & rainfall and snowmelt \\
\hline $\begin{array}{l}\text { Thresholds for different } \\
\text { type of landslides }\end{array}$ & yes & no \\
\hline Rainfall/water input & rainfall from rain gauge and weather radar & $\begin{array}{l}\text { water supply (rain }+ \text { snowmelt) and soil moisture, in- } \\
\text { terpolated from HBV model }\end{array}$ \\
\hline Type of thresholds & $\begin{array}{l}\text { ID thresholds for Alpine and Hilly environ- } \\
\text { ments for shallow slides; } \\
\text { radar hourly intensity rainfall thresholds for de- } \\
\text { bris flows in Alpine catchments; } \\
\text { antecedent precipitation thresholds for transla- } \\
\text { tional/rotational slides in hilly environment }\end{array}$ & $\begin{array}{l}\text { water supply vs. degree of soil saturation; } \\
\text { water supply vs. degree of soil saturation }+ \text { landslide } \\
\text { susceptibility; } \\
\text { water supply vs. degree of soil moisture }+ \text { soil frost }\end{array}$ \\
\hline $\begin{array}{l}\text { Methods for threshold } \\
\text { definition }\end{array}$ & $\begin{array}{l}\text { statistical approach } \\
\text { (Tiranti and Rabuffetti, 2010; Tiranti et al., } \\
\text { 2013, 2014) }\end{array}$ & $\begin{array}{l}\text { statistical approach } \\
\text { (Boje et al., 2014) }\end{array}$ \\
\hline Weather forecast & $\begin{array}{l}\text { COSMO I7 NWP model: for the first } 3 \text { days } \\
\text { with } 6 \text { h resolution; } \\
\text { weather radar QPE and storm-tracking now- } \\
\text { casting }\end{array}$ & $\begin{array}{l}\text { AROME MetCoOp model for the first } 3 \text { days as } 1 \mathrm{~km}^{2} \\
\text { raster maps, with } 24 \text { and } 3 \mathrm{~h} \text { resolution; } \\
\text { EC model for the following } 3 \text { days as raster maps } 1 \mathrm{~km}^{2} \\
\text { resolution } \\
+ \text { daily briefing with meteorologist on duty } \\
+ \text { visual inspection of radar during summer }\end{array}$ \\
\hline Monitoring instruments & $\begin{array}{l}\text { multi-sensor weather gauges }(<400) \text {; } \\
\text { two weather radars }\end{array}$ & $\begin{array}{l}\text { multi-sensor weather gauges }(\sim 400) \text {; } \\
\text { groundwater level }(80) \text {; water discharge }(\sim 350) \text {; other } \\
\text { instruments (snow water equivalent; soil water content } \\
\text { and soil temperature) }\end{array}$ \\
\hline Released warning & every day, befor & every day, before 11:00 and updated before 15:00 \\
\hline Warning valid & from 1 & $\begin{array}{l}\text { from } 07: 00 \text { the day of publication to } 07: 00 \text { of the fol- } \\
\text { lowing day ( } 08: 00 \text { to } 08: 00 \text { daylight } \\
\text { savings time) }\end{array}$ \\
\hline Warning days & $36 \mathrm{~h}(\mathrm{D} 0$ and $\mathrm{D} 1)$ & first 3 days (D0, D1 and D2) \\
\hline Warning zone & fixed (catchment) & variable (county/group of municipalities) \\
\hline $\begin{array}{l}\text { Number of warning } \\
\text { levels }\end{array}$ & 4 & 4 \\
\hline Warning web page & $\begin{array}{l}\text { http://www.arpa.piemonte.gov.it/rischinaturali, } \\
\text { last access: } 7 \text { May } 2018\end{array}$ & www.varsom.no, last access: 7 May 2018 \\
\hline Broadcast media & internet & internet, CIM (crisis information management) \\
\hline Susceptibility map & $\begin{array}{l}1: 100000 \text { scale (Tiranti and Rabuffetti, 2010); } \\
\text { Alpine catchments (Tiranti et al., 2014) }\end{array}$ & $\begin{array}{l}\text { catchment level (Bell et al., 2014) } \\
1: 50000 \text { scale (Fischer et al., 2012) }\end{array}$ \\
\hline Landslide database & $\begin{array}{l}>35000 \text { landslides and debris flows } \\
\text { https://webgis.arpa.piemonte.it/, last access: } \\
7 \text { May } 2018\end{array}$ & $\begin{array}{l}\text { > } 57000 \text { mass movements* } \\
\text { www.skredregistrering.no, last access: } 7 \text { May } 2018\end{array}$ \\
\hline $\begin{array}{l}\text { Landslide verification } \\
\text { after events }\end{array}$ & $\begin{array}{l}\text { internet, social media, newspapers and field } \\
\text { observations }\end{array}$ & $\begin{array}{l}\text { internet, http://regobs.no, last access: } 7 \text { May 2018, } \\
\text { newspapers and field observation }\end{array}$ \\
\hline Primary references & $\begin{array}{l}\text { Tiranti and Rabuffetti (2010); Tiranti et } \\
\text { al. }(2013,2014,2016) \text {; Stoffel et al. (2014) }\end{array}$ & $\begin{array}{l}\text { Colleuille et al. (2017); Piciullo et al. (2017); Krøgli et } \\
\text { al. (2017) }\end{array}$ \\
\hline
\end{tabular}

\footnotetext{
* landslides + snow avalanches + submarine landslides
} 


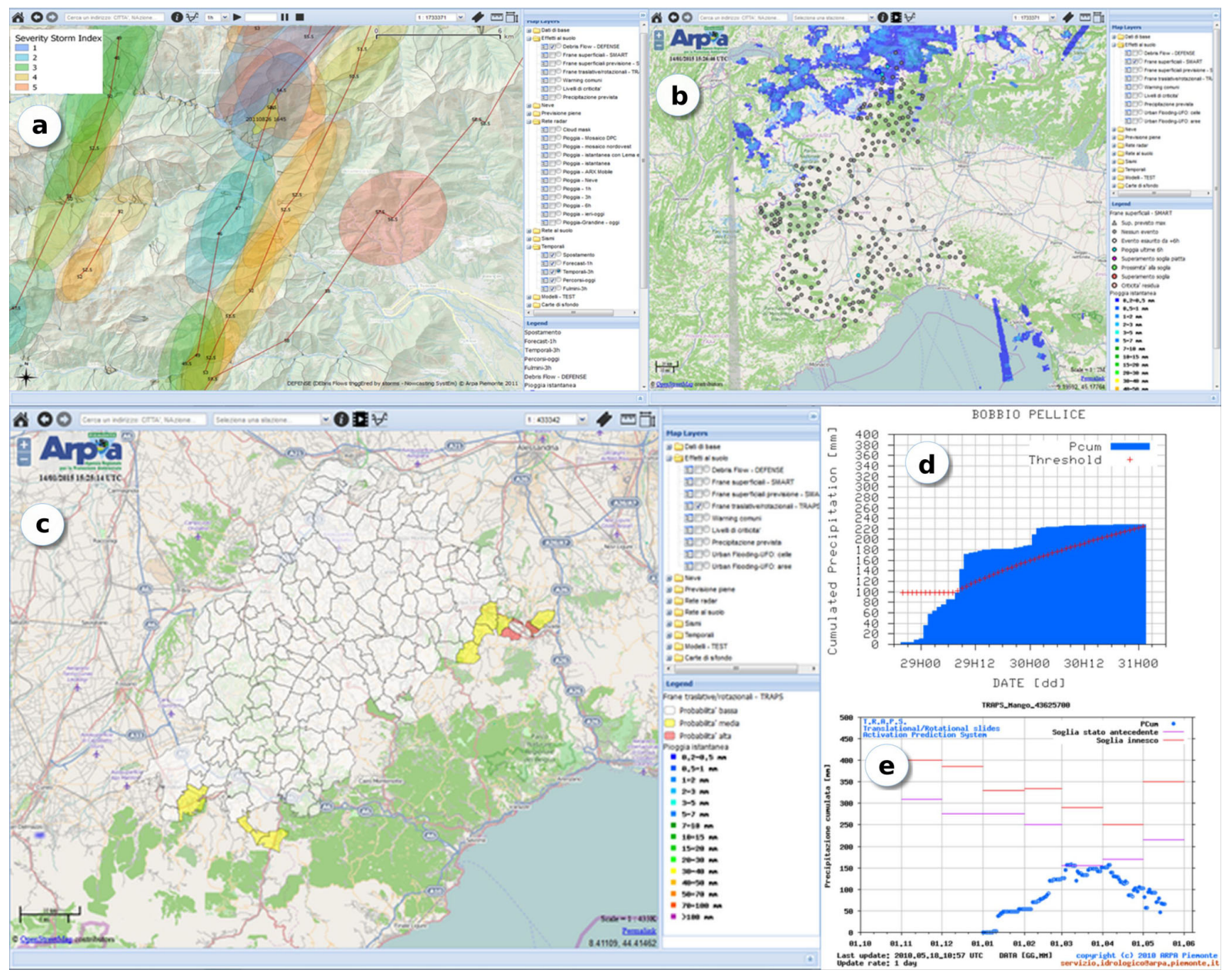

Figure 5. Examples of EWSs WebGIS interface. (a) DEFENCE: ellipses show storm cells, lines show storm paths, yellow polygon shows the catchment affected by debris flow triggering rainfall intensity; (b) SMART: dots represent the rain gauges linked to shallow landslides triggering thresholds; (c) TRAPS: polygons represent the areas characterized by different probabilities for translational landslide activation (white = low/null probability; yellow = medium probability; red = high probability); (d) an example of SMART threshold (red dashed line) representation related to accumulated rainfall (blue area) recorded by rain gauges; (e) an example of TRAPS diagram: blue dots are the antecedent precipitation values accumulated over previous 60 days, red lines are the monthly triggering threshold value and purple lines are the monthly predisposing thresholds (thresholds indicating the high probability of early instability; source: ARPA Piemonte).

with a corresponding water balance simulation. From temperature and precipitation as input variables, the model simulates forecasted hydro-meteorological variables such as rainfall and snowmelt, water supply, degree of soil saturation, ground water level compare to normal, soil frost depth, water feed capacity, etc. In addition to HBV, a second tool is a physically based model, S-Flow developed by NVE, which simulates water and heat dynamics in a column of layered soil covered by vegetation. The model uses also temperature and precipitation, but it requires also wind speed, relative air humidity and solar radiation as input data.

Unlike other countries, Norway does not use classical intensity-duration thresholds. Based on Guzzetti et al. (2008), the threshold used in Norway can be classified as "other thresholds", because they are based on analysis of his- torical landslides and water supply (e.g., rain and snowmelt) and the degree of soil water saturation (Fig. 6a). Both parameters are simulated from HBV model (Fig. $6 \mathrm{~b}$ and c). The first parameter is the water supplied to the soil from rain and snowmelt, expressed as percent of yearly normal water supply in the reference period 1981-2010, and is the product of simulated snowmelt and interpolated precipitation. The second parameter is the degree of soil saturation described in percent between the present soil water content compared to the maximum soil water content in the same reference period. The thresholds were derived using tree classification system. Generally, the thresholds indicate increased landslide hazard when values of water supply are greater than $6-8 \%$ of the mean annual precipitation combined with a simulated soil water saturation degree greater than $60 \%$. Three thresholds 


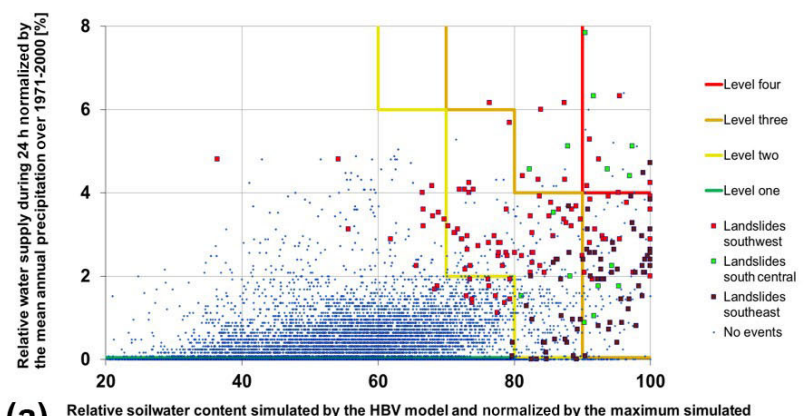

(a) Relative soilwater content simulated by the HBV model and normalized by the maxim
soil water content (assumed fully saturated soil) during $1990-2008[\%]$

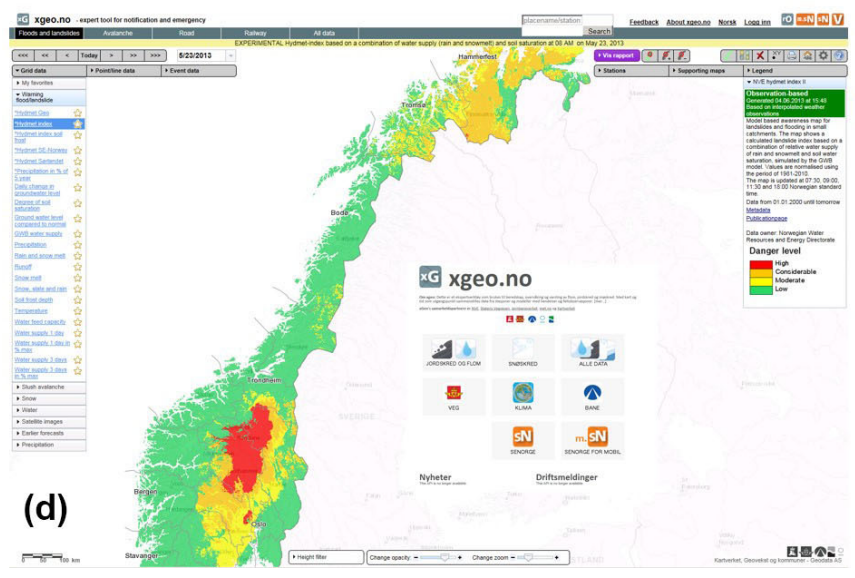

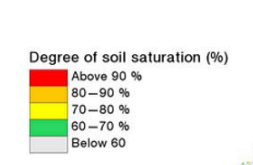

(b)

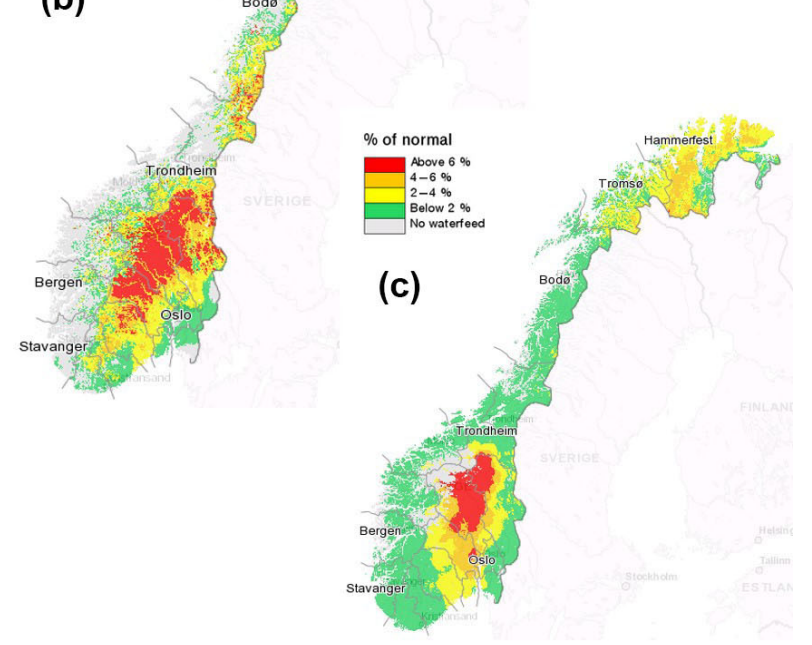

Figure 6. Landslide thresholds and WebGIS interface xgeo.no. (a) National landslide thresholds based on simulated degree of soil saturation and water supply obtained from HBV model; (b) map of simulated degree of soil saturation. The percent describes the relationship between today's soil water storage compared to the maximum soil water storage simulated with the HBV model in the reference period 1981-2010; (c) map of simulated water supply (rain and snowmelt) the last $24 \mathrm{~h}$ as percent of yearly normal water supply in the period 1981-2010, and is the product of simulated snow melt and interpolated precipitation; (d) the web interface xgeo.no with the Hydmet landslide thresholds map in the background. The map represents the national landslide thresholds presented in (a) and is obtained by combining the maps in (b) and (c). The maps in (b)-(d) are examples from 22 May 2013 and extracted from http://xgeo.no.

are used to separate conditions similar to warning levels of green, yellow, amber and red (Fig. 6a). Since the thresholds were derived from tree classification technique, the threshold consists of several linear equations generating thresholds with a ladder shape. Thresholds are unique for all landslide processes. They were derived initially for the entire country from a few storms events in southern Norway, but recently thresholds have been defined to include landslide events from other regions (Boje, 2017). The spatial distribution of the thresholds is visualized as raster data (with $1 \mathrm{~km}^{2}$ resolution) at http://xgeo.no (Fig. 6d). In order to consider issuing a warning the threshold map should display a regional impact over a county or over a group of municipalities. Recently the thresholds have been combined with landslide susceptibility maps at catchment levels and better thresholds are available that help to reduce the warning area. Expert knowledge is fundamental to the daily landslide hazard assessment, and, to decide the final assessment and extension of warning levels. An organization flow chart is presented in Piciullo et al. (2017).

\section{The Vb cyclones}

Floods and landslides are important secondary effects of high-impact weather events, like tropical and extra-tropical cyclones, as they are accompanied by extremely strong winds and heavy precipitation. Central Europe and the northern Alpine region are exposed to high-impact events associated with the $\mathrm{Vb}$ cyclones (Messmer et al., 2015). This type of cyclone was mentioned by Köppen (1881) and later, defined by Van Bebber $(1882,1891)$ who proposed a cyclone classification system based on the main storm circulation trajectories in Europe (Messmer et al., 2015; Roald, 2008), describing one of them as $\mathrm{Vb}$. In later classifications like GWL/SVG proposed by James (2007), this synoptic weather regime is known as 11 TM "Tief Mitteleuropa = Low (Cut-Off) over Central Europe", while in the GWT classification it is known as "TME Central European low".

The origin of $\mathrm{Vb}$ cyclones is the Bay of Biscay, the Balearic Sea or the Ligurian Sea, where moisture uptake occurs. The cyclone moves eastward over the southwestern part of France and over the Mediterranean Sea, where it refills 
with moisture and energy. Then, $\mathrm{Vb}$ cyclones move across northern Italy and the Adriatic Sea before they turn eastward towards the Black Sea and later northward across eastern Europe, and finally towards Scandinavia (Fig. 7).

The $\mathrm{Vb}$ cyclones are characterized by very warm and humid air masses from the central Atlantic and Mediterranean, with cold air masses linked to depressions in the northern part of the Atlantic forming a quasi-stationary front with extremely heavy rainfall (Fig. 7). The synoptic configuration is linked to blocking anticyclones in the North Atlantic and over Finland or the Kola Peninsula. This weather circulation occurs typically on July or August, but in recent years it has been observed in late spring (April, May and June).

Most of studies on $\mathrm{Vb}$ cyclones presented case studies of floods induced by $\mathrm{Vb}$ cyclones, focusing on the source of moisture, while only few studies focused on analyzing the decrease or increase of number of cyclones. A description of the basic climatology of this weather type is provided in Messmer et al. (2015), given insight into the Vb cyclones' variability and investigating their physical mechanisms.

These cyclones transport large amounts of atmospheric moisture to central Europe and northern side of the Alps, thus triggering extreme precipitation events (Messmer et al., 2015). The potential of transporting extreme precipitation to central Europe is especially high if these cut-off low systems are positioned in the northern or eastern parts of the Alps (Awan and Formayer, 2016). There is agreement in the literature on the large-scale dynamics of $\mathrm{Vb}$ events, which indeed seem to determine whether a $\mathrm{Vb}$ cyclone delivers high precipitation or not (Messmer et al., 2015). Even if they are rare events, 2.3 per year (Messmer et al., 2015), the $\mathrm{Vb}$ cyclones are highly relevant for Europe because of their potential to produce extensive precipitation and subsequent floods, particularly during the warm season, and often in Austria, Switzerland, Germany, Poland and the Czech Republic. The $\mathrm{Vb}$ cyclones are well known among hydrologists and meteorologists to have caused most of the largest floods in central Europe, including on the Elbe, Danube, Rhine catchments and Alpine areas, for example: 1000-year flood in 1342 on the Elbe, Danube and Main; the Oder flood in July/August 1997; flooding on the Elbe and Danube in August 2002; flooding in Austria and Switzerland in August 2005. Less mentioned in international literature is the fact that this weather is responsible for extensive flooding events and triggering landslides, including in the southern sector of the Alps and in Norway. Roald (2008) documented many flood events caused by $\mathrm{Vb}$ cyclones in southeastern Norway, including in July 1789, in 1860 and more recently in June 2011, among others.

\section{Meteorological conditions in late spring 2013}

The meteorological pattern that affected Europe in late spring 2013 started at the end of April 2013 and lasted until the be-

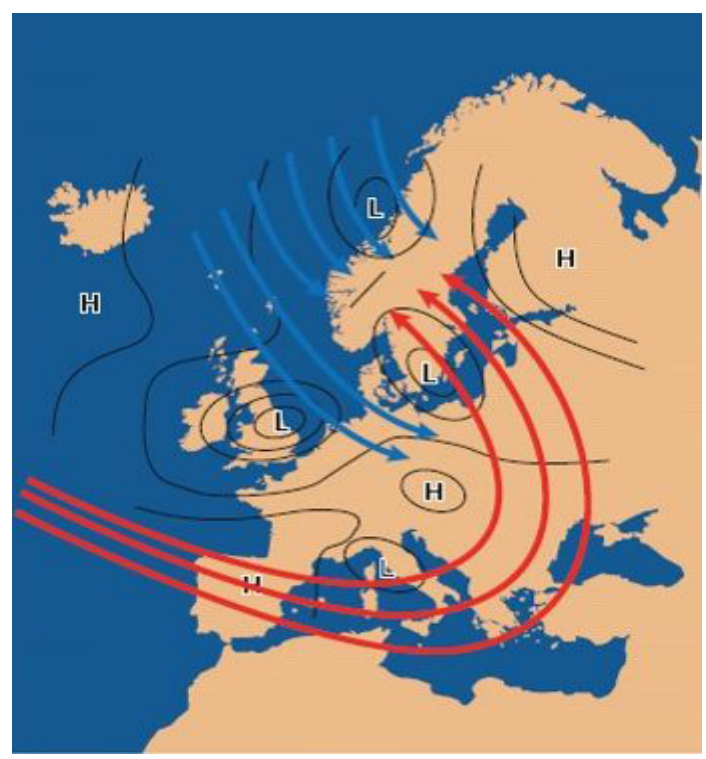

Figure 7. Southern type of weather: Vb trajectory. " $\mathrm{H}$ " is high pressure and " $L$ " is low pressure. Red lines indicate warm and humid air, while blue lines represent cold air masses (source: NVE).

ginning of June 2013. In Piedmont major impacts were observed in the first half of this period, while in Norway they occurred from 15 May to 2 June 2013.

\subsection{Antecedent conditions}

Winter $2012 / 2013$ was relatively cold $\left(-0.23^{\circ} \mathrm{C}\right.$ respect the 1977-2001 average temperature) and dry ( $-52 \%$ respect 1977-2001 average precipitation) in both countries with temperature lower than normal. It was still cold in Piedmont from March to May, but wetter than in Norway. In March, rainfall in Piedmont was $+30 \%$ above normal and heavy precipitation occurred at the end of April. Between 27 April and 1 May 2013 several rain gauges in northwestern Piedmont recorded more than $250 \mathrm{~mm}$ in 5 days (against $175 \mathrm{~mm}$ average April precipitation).

In southeastern Norway, the period January-April 2013 was colder and drier than normal and characterized by cool air from the north (Roald, 2015). The average temperature was $2-3^{\circ}$ below the normal in this area especially in the interior northwestern part close to the mountains. Spring arrived late. The period January-April was characterized by precipitation deficits in many areas. The precipitation was $90 \%$ of normal over the entire country; however, southeastern Norway received only 25 to $50 \%$ of normal precipitation. The snow depth was lower than normal and thus ground frost deeper than normal. In May, the warm air from the south and southeast initiated snowmelt in the mountains. Figure 8 shows the snow distribution in Norway during April-May 2013. In the middle of May, there was still snow cover above $700 \mathrm{~m}$ a.s.l. and more snow depth than normal in the west- 


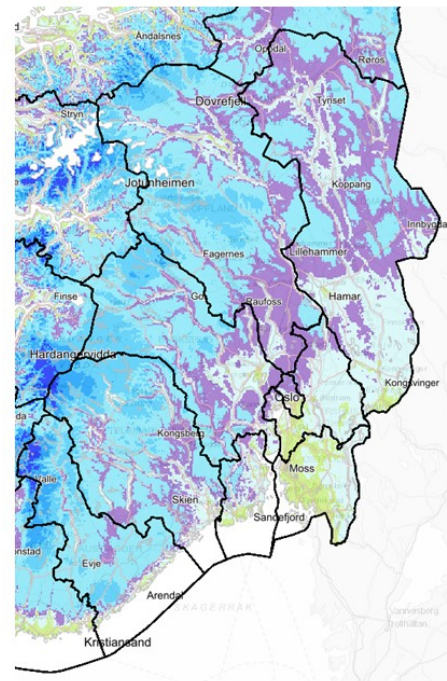

(a)

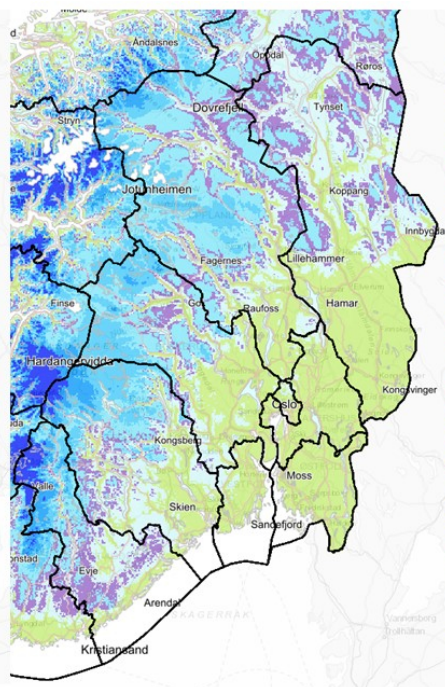

(b)

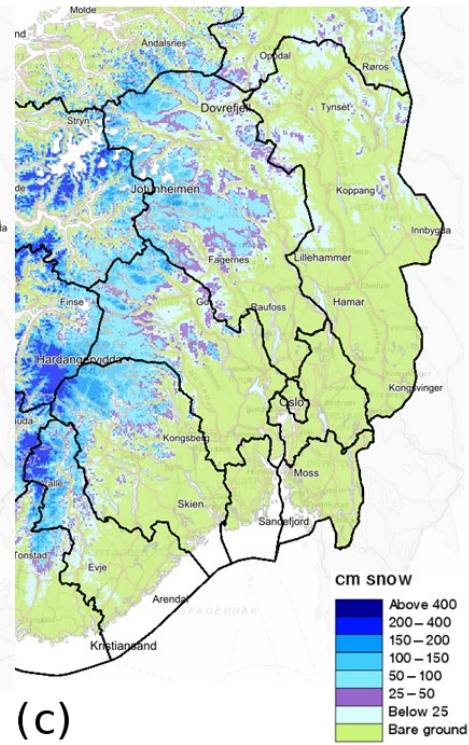

(c)

Figure 8. Snow distribution (a) middle of April, (b) end of April and (c) middle of May, Norway (source: http://xgeo.no).

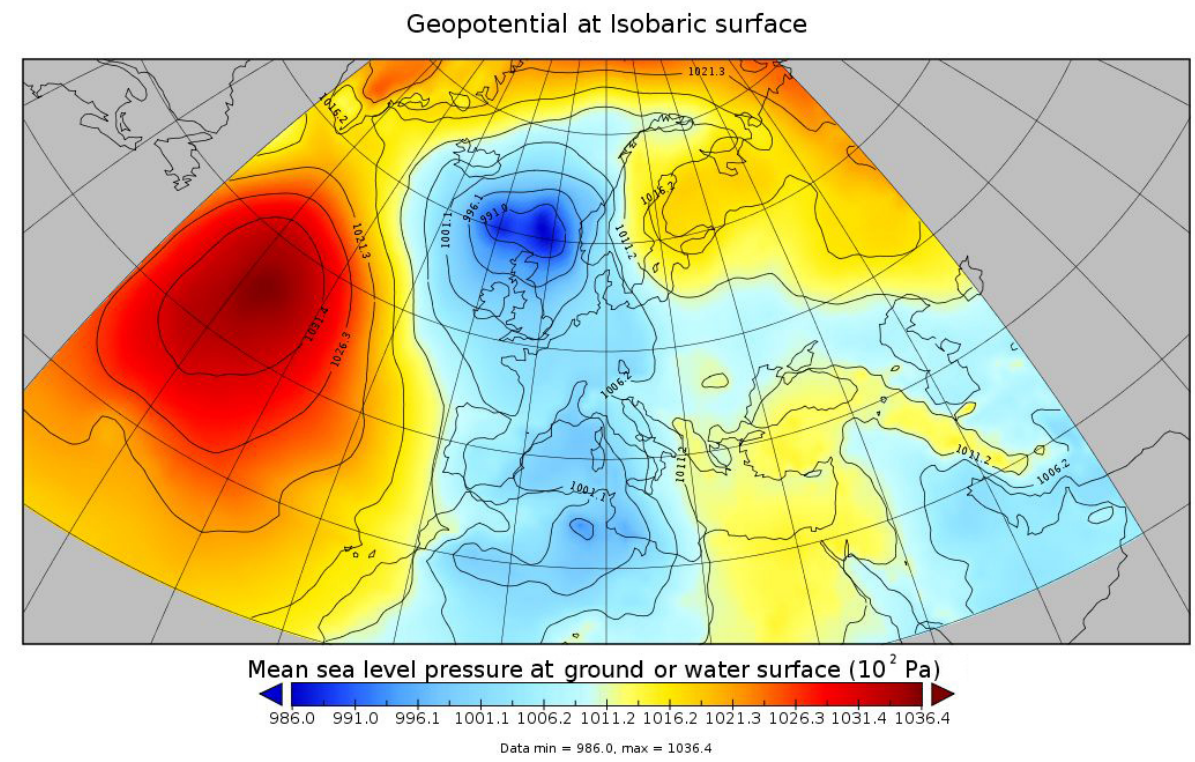

Figure 9. ECMWF mean sea level pressure analysis over Europe on 16 May 2013 at 00:00 UTC (source: ARPA Piemonte).

ern part of the area. In May precipitation was $+200-500 \%$ above average, especially in the western parts of the area.

\subsection{Meteorological conditions during the period analyzed}

The $\mathrm{Vb}$ atmospheric pattern influenced weather in Europe, and in particular in Italy and Norway, for a long period over spring 2013, from the end of April until the beginning of June 2013. In retrospect, it could be observed that the $\mathrm{Vb}$ weather regime was relatively easy to follow across the Mediterranean Sea. In the initial phase, the $\mathrm{Vb}$ cyclone was responsible for strong winds (up to $120 \mathrm{~km} \mathrm{~h}^{-1}$ ) that produced sandstorms in Malta and southern Italy (particularly in Sicily and Calabria) on 15 and 16 May 2013 with some impacts on the population (Meteoweb, 2013). When the system moved north, it was responsible for producing intense rainfall in proximity of the western Alps. The $\mathrm{Vb}$ system continued to northern Europe bringing warm air at higher latitudes and rainfall when it reached in southern Norway. 


\subsubsection{Piedmont}

From 15 to 19 May 2013, an intense cold front affected Piedmont, causing abundant precipitation, a general increase of rivers discharge and vast areas of Piedmont to be affected by floods and landslides.

On 15 May 2013, a trough over western Europe conveyed warm and wet flows from south towards Piedmont, causing widespread precipitation that intensified especially in northern Piedmont and on the border areas with Liguria. Figure 9 shows the mean sea level pressure analysis by the global numerical weather prediction model operated by the European Centre for Medium-range Weather Forecasts (ECMWF) on 16 May 2013, 00:00 UTC. The main low-pressure system is centered over the North Sea, while a secondary one is near North Africa coasts: isobars determine intense southern humid air flow from Mediterranean Sea towards Scandinavian Peninsula.

Widespread moderate, but locally strong, precipitation affected Piedmont at night. In the Po Valley on average $30-40 \mathrm{~mm}$ of rainfall with a maximum of $45.6 \mathrm{~mm}$ over $24 \mathrm{~h}$ were recorded. About $20-25 \mathrm{~cm}$ of fresh snow were recorded in the Alps above 2000 ma.s.1. On 16 May 2013, the low-pressure area, responsible for severe weather, gradually moved towards Biscay Bay, continuing to convey wet and unstable air over Piedmont. However, an increase of atmospheric pressure in Ligurian Gulf caused an attenuation of meridional flows and a general attenuation of precipitation. In the late evening, the cold front associated with the low pressure crossed Piedmont, causing instability and convective rainfall, more intense over the northwestern foothills. On the afternoon of 17 May, the cold sector that had affected Piedmont over the previous $48 \mathrm{~h}$ passed, leading to a general attenuation in rainfall. However, atmospheric postfrontal instability caused sporadic thunderstorms, particularly on the western foothills, where the interactions between southern flows and Alpine foothills caused strong connection with abundant hail: hourly precipitation rates reached up to $40 \mathrm{~mm}$. Discharges of minor hydrological networks increased as result of severe thunderstorms. On 18 May 2013, the occluded front passed Piedmont from west to east. The wet airflow from the south remained intense, resulting in convergence close to the northwestern foothills, with further intensification of rainfall. On the morning of 19 May, the sea level pressure increased, leading to precipitation exhaustion, except for northern Piedmont where rainfall terminated over midday. The rainfall between 18 and 19 May resulted in significant increases in rivers discharge both in northern and southern basins. Dangerously high levels were reported across secondary hydrological networks, particularly in the basins near Turin. Over the entire period, more than $300 \mathrm{~mm}$ fell in northwestern areas with peaks of $350 \mathrm{~mm}$ in $96 \mathrm{~h}$ (Fig. 10). The return period for 3-6 h rainfall accumulation were about 20 years. Finally, several catchments recorded more than $600 \mathrm{~mm}$ from 1 March 2013 to mid-May.

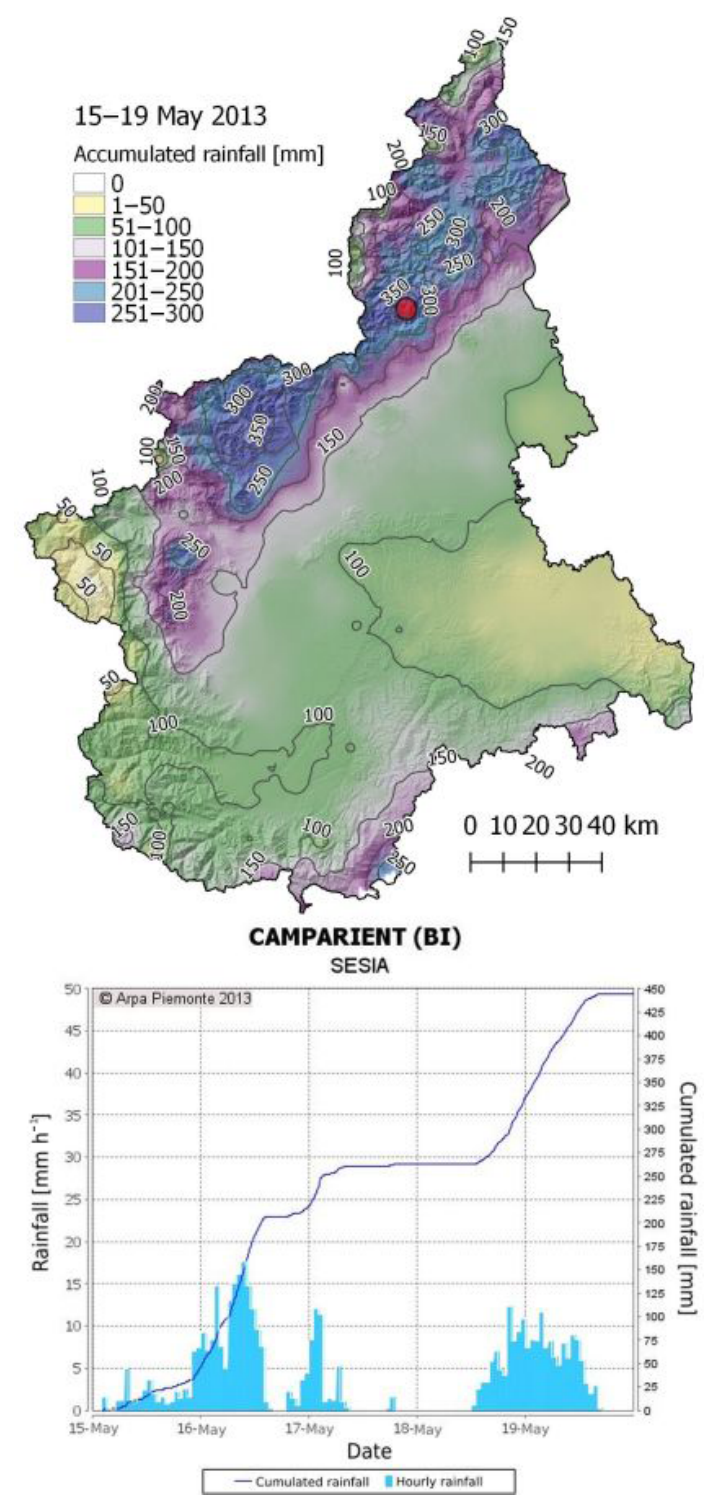

Figure 10. Accumulated rainfall from 15 to 19 May 2013 (source: ARPA Piemonte). An example of rainfall distribution during the event, the histogram recorded by Camparient rain gauge (red dot in the accumulated rainfall map), is shown.

\subsubsection{Norway}

It is well known in Norway that $\mathrm{Vb}$ cyclones can produce the largest floods during spring (Roald, 2008). Therefore, every year the flood forecasting service at NVE, pays attention to these weather conditions in southern Europe. The arrival of the Vb cyclone in May 2013 was forecasted some weeks in advance by noting the possible arrival of a warm weather system from south (as it was indicated in a "situation report" published on 3 May). The Vb cyclone brought warm winds with high temperatures that caused intense snowmelt over a large area. The temperature starts to increase around 5 May in the mountain area, starting the snowmelt process. A short 

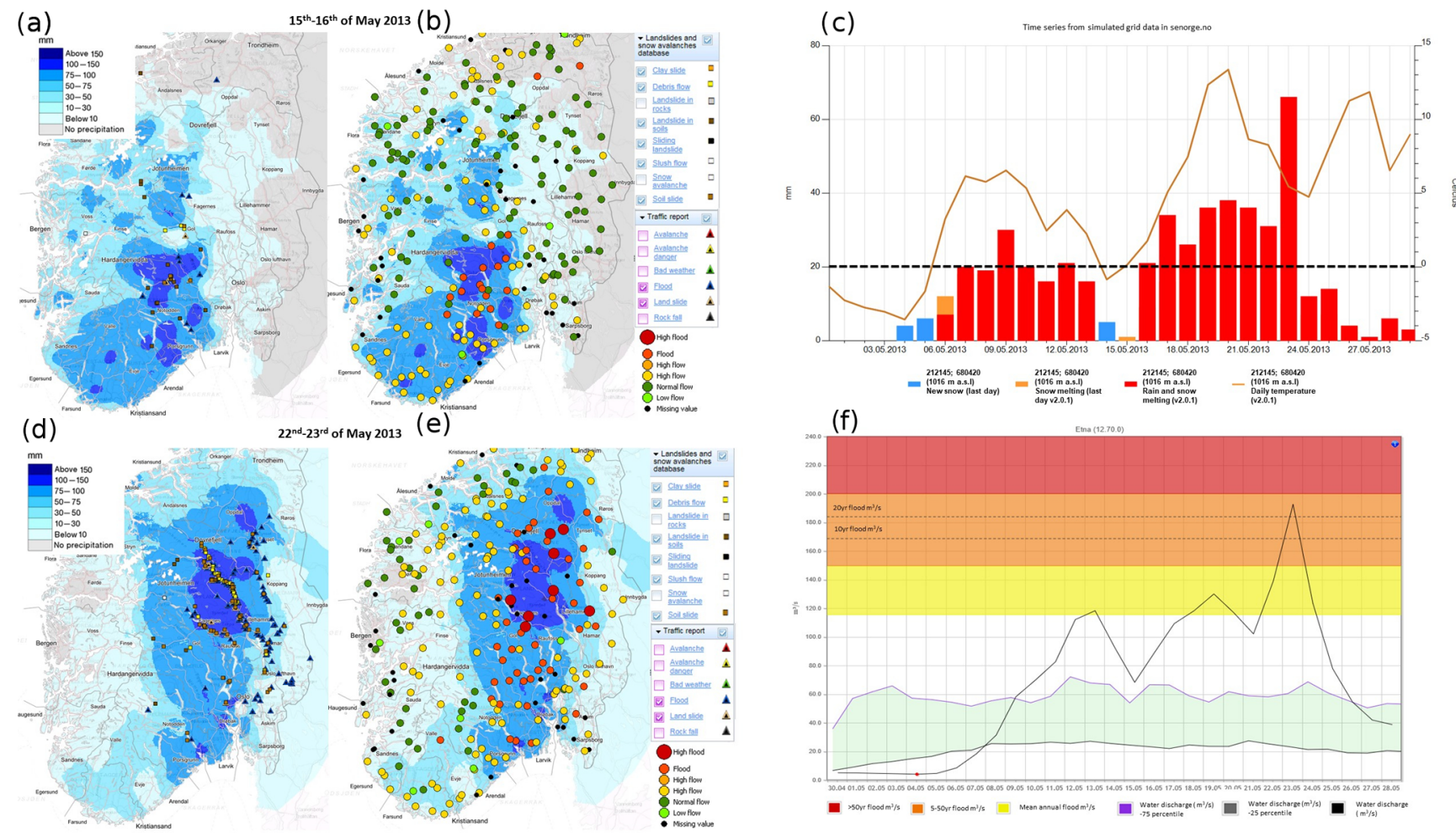

Figure 11. Events of 15-16 and 22 May. (a) Rainfall measurement from 15 and 16 May and landslide events; (b) rainfall measurement from 15 and 16 May and water discharge level; (c) rainfall and temperature distribution in May in the Gudbrandsdalen area (red: rainfall; blue: new snow; orange line: temperature); (d) rainfall measurement from 22 and 23 May and landslide events; (e) rainfall measurement from 22 and 23 May and water discharge level; (f) water discharge at Etna station during May 2013 (source: http://xgeo.no).

decrease in temperature was observed on 14-15 and 22 May before and during of the two main rainfall episodes. Temperatures reached the highest peak on 18 and 19 May, causing significant snowmelt in the area. Due to the arrival of several warm air fronts, temperatures continued to increase consistently until the end of May.

The first rainfall arrived on 15-16 May in the eastern counties of Telemark and Buskerud (Fig. 11a). At Eggedal station $60 \mathrm{~mm}$ of rain was measured in $24 \mathrm{~h}$. In this area, many hydrological stations reach the flood level (Fig. 11b) and in Eggedal the water discharge was the fourth highest since recording started in 1972, resulting in a big flood.

Precipitation started in the western counties, moving eastward. A second and more significant rainfall episode occurred on 22 and 23 May affecting mainly the Glomma and Østerdalen catchments in the eastern sector of the region (Fig. 11d). This initiated a large flood along Glomma River. In Østerdalen $50-60 \mathrm{~mm}$ of rain was measured that day, while in Gudbrandsdalen values ranged from 50 to $93 \mathrm{~mm}$. An overview of the rainfall and temperature distribution during May 2013 in the Gudbrandsdalen area is presented in Fig. 11c. The two rainfall episodes, in addition to the incoming snowmelt, were responsible for the increase of groundwater in the region and for producing high water discharge in many of the rivers in the area (Fig. 11e). A flood of 100year return period was observed for the Folla river, while in Numedalslågen and Skien catchments, a 30-year return period flood was observed (Roald, 2015). In Drammen river at Begna, Etna and Dokka stations, the flood reached the 50year return period (Fig. 11f). At Gausdal and Gudbrandsdalen, the rivers' flooding was estimated to be between a 50and 100-year return period. The $\mathrm{Vb}$ situation persisted from 15 May to 2 June and also caused intense rainfall and urban flooding in the capital Oslo on 2 June.

\subsection{Warning levels}

The warning levels indicate landslide hazards and generally which actions should be undertaken to reduce damage. The ARPA Piemonte and NVE services use similar levels shown in the typical traffic lights colors, summarized in Table 2. Even if the numbering of the levels is different, the meaning of the warning is similar. Emergency response authorities should be prepared to implement emergency plans, mitigation measures, evacuations and other contingency responses. Hazard and risk maps are necessary to help local authorities to prioritize the implementation of measures.

In Norway, warning levels are updated 2 times a day. The warning messages are sent from $66 \mathrm{~h}$ to a few hours ahead. 
Table 2. Warning levels in use in Italy and Norway.

\begin{tabular}{|c|c|c|c|}
\hline Warning level & Italy & Norway & Explanation \\
\hline Red & 3 & 4 & $\begin{array}{l}\text { Very high landslide hazard. Many landslides and several with large areas may occur; their long } \\
\text { runout and extent may result in damage to settlements and infrastructure. Red level is an extreme } \\
\text { situation that occurs very rarely. Emergency response authorities should implement emergency } \\
\text { plans, take safety measures, such as road closures, and carry out evacuations. Follow authorities' } \\
\text { recommendations. }\end{array}$ \\
\hline Orange & 2 & 3 & $\begin{array}{l}\text { High landslide hazard. Many landslides and some with large areas are expected. Incidents that } \\
\text { can impact infrastructure and roads may occur. Emergency response authorities should be vig- } \\
\text { ilant, prepared to implement emergency plans, evaluating the needs for evacuation, and carry } \\
\text { out safety measures. Exposed roads may be closed off. Pay attention to media and follow rec- } \\
\text { ommendations from the authorities. }\end{array}$ \\
\hline Yellow & 1 & 2 & $\begin{array}{l}\text { Moderate landslide hazard. Primarily small slides may occur, on artificial slopes that may affect } \\
\text { roads or railways or are along river embankments. Sparse debris avalanches or debris flows } \\
\text { (also with large areas) may also occur causing damage to infrastructure or injury, but primarily } \\
\text { on a local scale. Emergency authorities should increase vigilance and pay attention to weather } \\
\text { conditions and landslide forecasts. Preventive measures are recommended. }\end{array}$ \\
\hline Green & 0 & 1 & $\begin{array}{l}\text { Generally safe conditions. Debris avalanches, debris flows, shallow slides and slush flows are } \\
\text { not expected at this level. }\end{array}$ \\
\hline
\end{tabular}
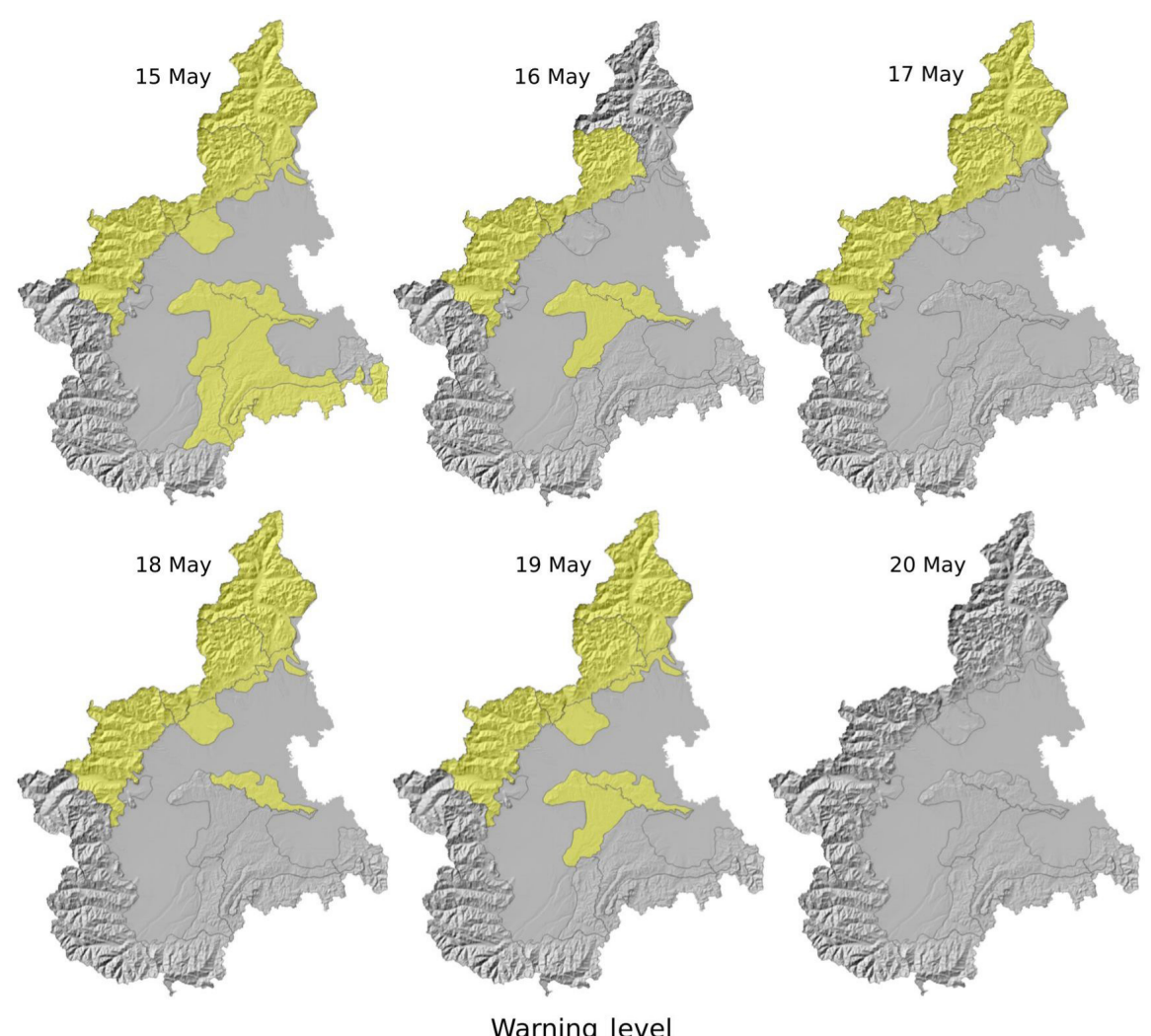

No warning

Isolated landslides

Landslides $<10 \mathrm{~km}^{-2}$

Landslides $>10 \mathrm{~km}^{-2}$

Figure 12. Landslide warnings issued from 15 to 20 May 2013 in Piedmont region (source: ARPA Piemonte).

On 15 May 2013 the first warnings in northwestern Alps and in central hilly areas about possible debris flows and landslides were issued by ARPA Piemonte (Fig. 12). Then, according to observed precipitation and updated NWP out- puts, the warning levels remained stable over Alps, while alerted hilly areas reduced. Given the rainfall observed during 18 May and the first hours of 19 May 2013, the first warn- 


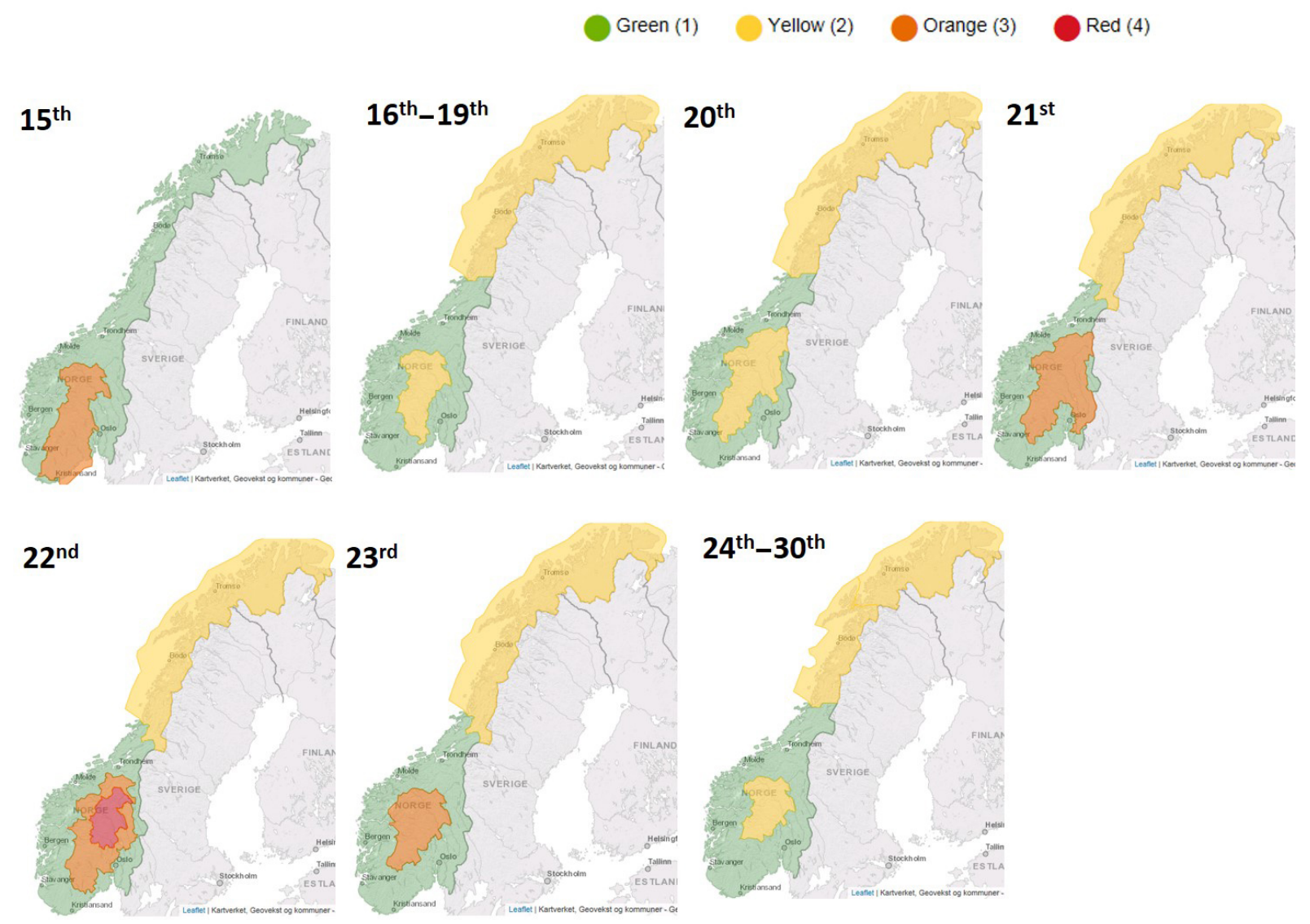

Figure 13. Landslide warnings issued from 15 to 30 May 2013 in Norway (source: http://varsom.no).

ings for local floods, debris flows and landslides were issued for central Piedmont.

The first flood warning was issued in Norway on 14 May 2013, followed by the first landslide warning (orange level) on 15 May for parts of the southeastern region. A yellow level was maintained from 16 to 20 May. On 21 May the level was increase to orange and on 22 May it was increased to red (Fig. 13). Different landslide warnings were issued every day until the end of May as shown in the Fig. 13. From 16 May until the end of May a yellow warning was also issued for northern Norway.

The severity of the rainfall and snowmelt episode that occurred on 22 May was clearly detected some days in advance, when the Hydmet map shows that landslide thresholds would be exceeded (Fig. 14).

\section{Type of landslides and economic consequences}

In Piedmont, after these rainfall events, about 320 slope phenomena were reported (300 landslides and 20 channelized debris flows; Fig. 15). The main landslide types were wide shallow landslides, deep-seated rotational slides in Alpine and hilly areas and subordinated reactivation of some trans- lational slides in hilly environment. The territory hit by slope and flood processes (Fig. 16) covers an area of $3700 \mathrm{~km}^{2}$ with about 420000 inhabitants. There are important connecting transport routes, included international ones, in the affected areas. Due to the occurrence of severe phenomena, numerous cases of traffic interruptions by landslides and flood were reported, as well as flooding of buildings, deposition of coarse alluvial sediments on roads, bridges jammed by debris flows, roadside wall collapse, erosion of roads surface, urban flooding and people trapped in cars. The rainfall events caused widespread damage, affecting the community's residential areas economic livelihood.

Figure 17 shows the warning areas issued (in yellow) and the municipalities where landslides were reported (in red): the contingency table derived gives a probability of detection (POD) equal to 0.70 (benchmark equal to 1 ) and a false alarm ratio (FAR) equal to 0.63 (benchmark equal to 0 ).

In Norway, more than 100 landslides were recorded in the database (www.skredregistrering.no) in this region between 15 May and 7 June. Mainly the events that reached roads and railway were recorded, but we believe that many more occurred, but they were not reported due to their location in less inhabited areas. Figure 11a shows the spatial distribution of landslides during the first rainfall event and Fig. 11d 


\section{Prognosis of landslide thresholds}
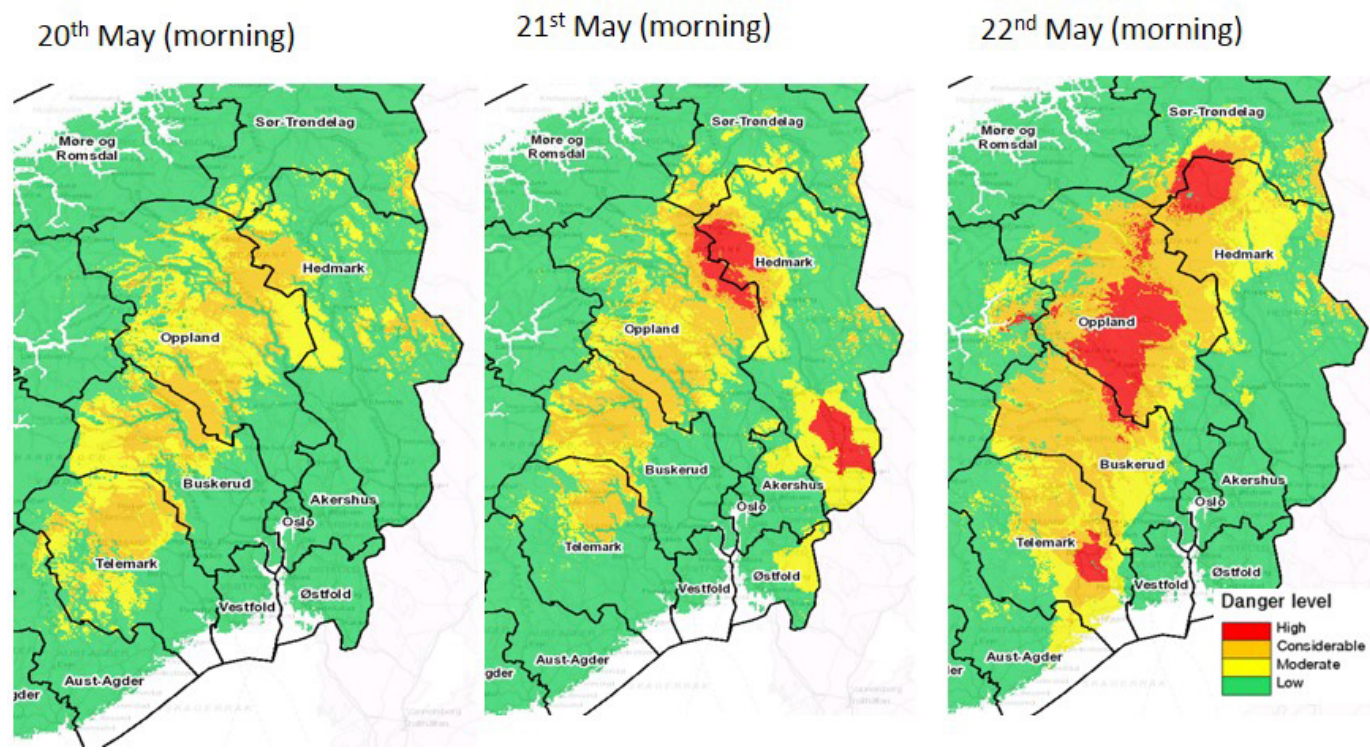

Figure 14. Prognosis of landslide thresholds (source: http://xgeo.no).
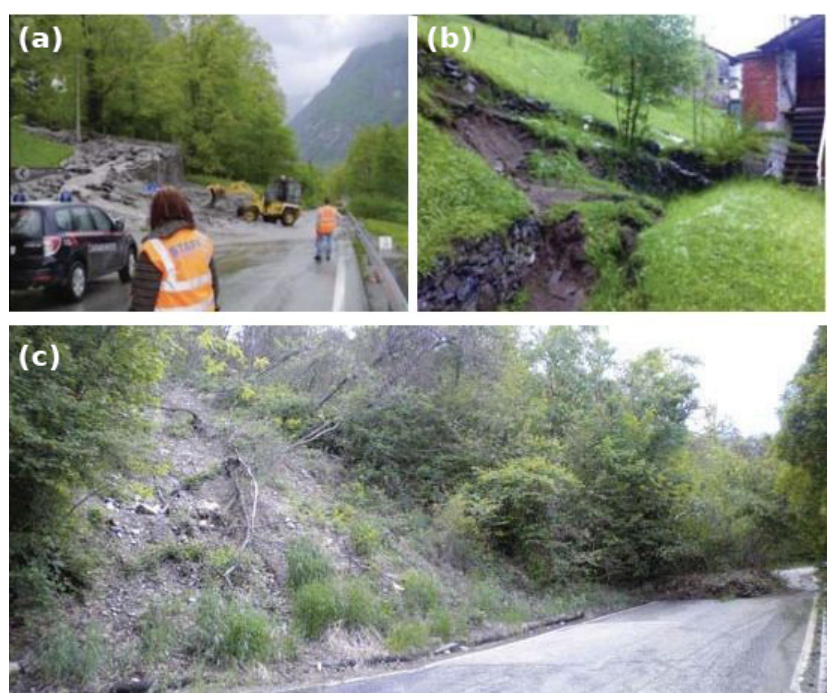

Figure 15. Some examples of slope phenomena recorded during rainfall event. (a) Road interrupted by a debris flow; (b) a building hit by small rotational slide; (c) shallow landslides on a road (source: Regione Piemonte).

shows the landslides from the second rainfall event. Both figures indicate the areas where roads were blocked because of flooding. The landslides observed were mainly debris flows and a combination of debris slides and debris flows; however, most of them were reported generically as landslides in soil (Fig. 18). There were many shallow slides in artificial cuts, mainly translational slides with small areas or along river sides. A few slush flows were also reported, especially in the northern sector of the region in the mountains. The landslide events and floods produced significant damage to roads, railways and private buildings and the economic losses were estimated around $\sim$ EUR 170 million $(\sim$ NOK 1.5 billion) for 22 May. Many places were evacuated for several days. There were 350 cases of damage and 23 municipalities asked for mitigation measures in Hedmark and Oppland. The same system triggered landslides and floods in northern Norway, but this is outside the scope of this paper.

\section{$7 \quad$ Discussion and conclusions}

Two territorial landslide forecasting and warning services operating in two European countries, Italy and Norway, have been presented and compared. They were designed to predict rainfall- and snowmelt-induced landslides, a general term used to refer to rapid mass movements, like shallow translational and rotational slides, channelized debris flows and debris avalanches. The Norwegian system is also able to predict slush flows. The organization of both services started at governmental level in the late 2000s as part of and in synergy with flood and snow avalanche forecasting services. Using statistical methods landslide thresholds were derived. Rainfall ID thresholds are used in Piedmont defined for the different types of landslides, while in Norway a unique threshold based on water supply (rain and snowmelt) and soil moisture is used for all type of landslides and for the entire country. However, regional adaptation of the thresholds are in progress. Landslide thresholds can be visualized in form of maps in their respective web interfaces and expert tools. 

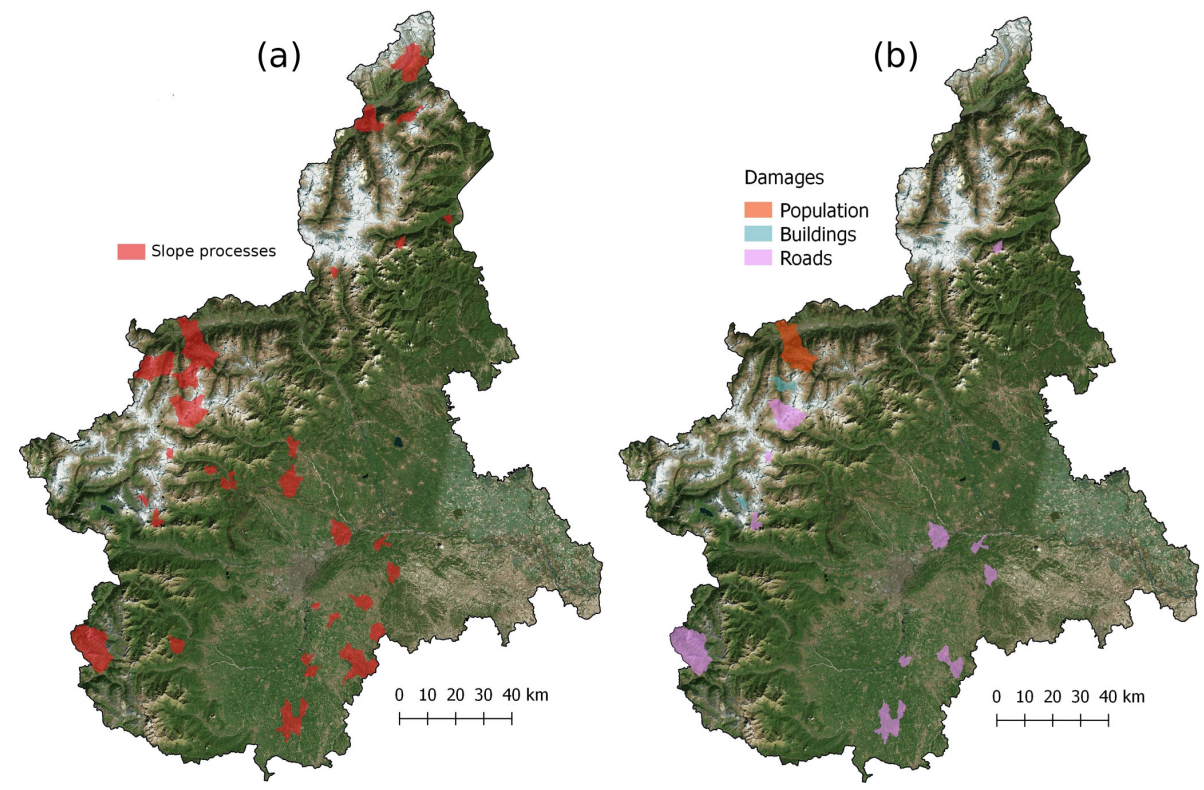

Figure 16. (a) Landslide processes occurring during the rainfall event. (b) Reported landslide damage (source: ARPA Piemonte).

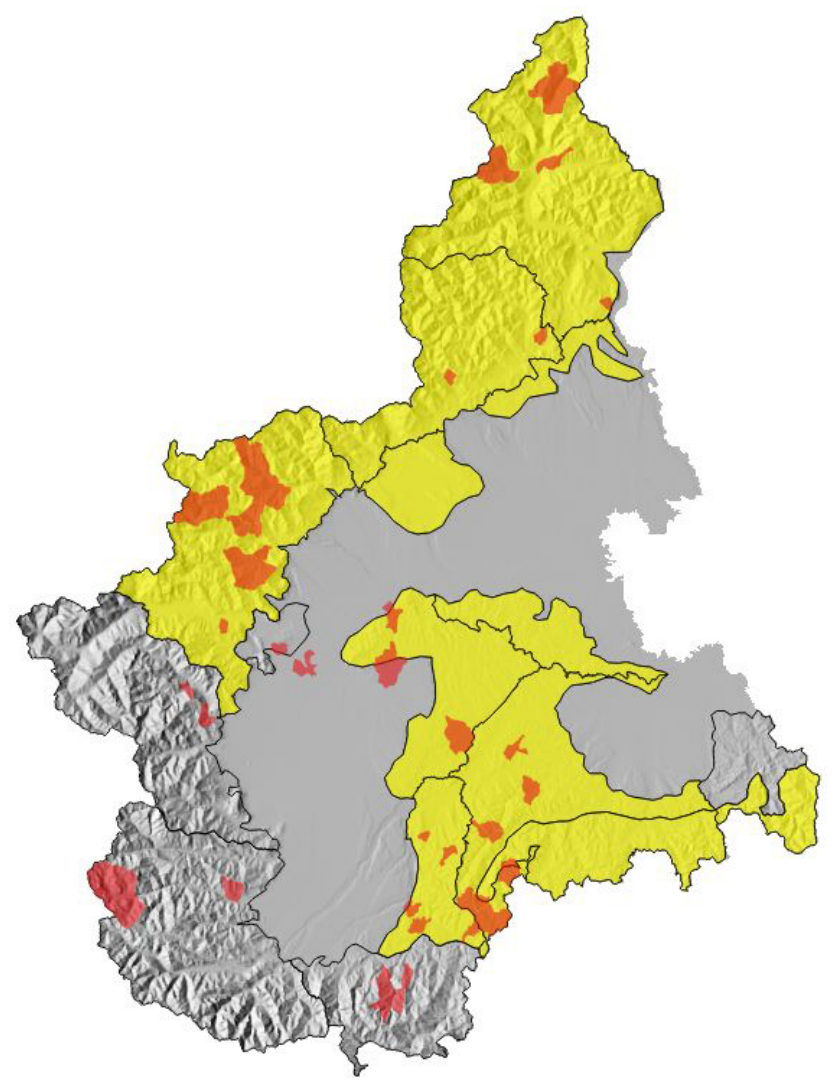

Figure 17. Warnings issued (yellow polygons) and wide landslide areas (red polygons) observed during the event.
Daily landslide hazard assessments are made on the basis of expert knowledge combined with quantitative thresholds, regular rainfall forecasts and real-time observations. Both services use four warning levels, which are published and disseminated through the internet. Information from news and field survey are used to verify the landslide occurrence. The evaluation of the performance of the systems is ongoing.

In this study, we presented a case of successful forecasted landslide events, triggered by the same large atmospheric synoptic pattern, the $\mathrm{Vb}$ cyclone, that occurred across Europe in May 2013. Even if Vb cyclones are rare phenomena, and are expected to decrease in frequency in the future (Messmer et al., 2015), they are serious challenges for forecasting services and emergency response authorities in the spring, because they are large atmospheric patterns that can affect areas for a long time and produce large floods and hundreds of landslides. The Vb cyclone in 2013 triggered flood and hundreds of landslides, mainly debris flows, debris slides and shallow slides both in Piedmont, northwestern Italy, and in Østlandet region, southeastern Norway, producing severe damage to infrastructure and buildings. The type of landslides triggered by the described event were similar in both countries, such as debris flows, debris slides and relatively shallow slides, not particularly large in terms of volume, but large in number and spread throughout the regions, causing significant damage to infrastructure and isolating communities because of blocked roads and railways. Even if Piedmont and Norway forecasting services worked separately, and they differ in some components (like landslide thresholds) they emitted accurate warning messages at regional level that were extremely useful for road and railway administrations and municipalities. Based on these warnings, 


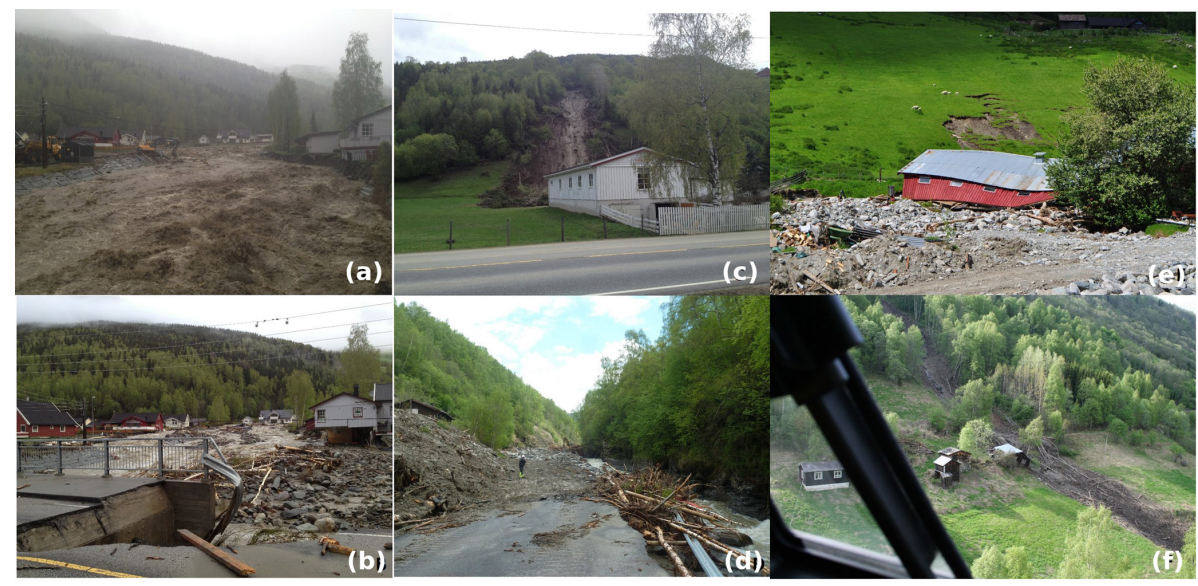

Figure 18. Flood and landslides at Kvam, Nord Frøn, Oppland, 22 May 2013. (a) and (b) flooding and flood damage at Kvam; (c) debris slide at Ringebu; (d) debris flow at Veikledalen; (e) shallow debris slide and debris flow deposits at Kvam; (f) debris flow at Veikledalen (source: NVE).

stakeholders activated timely emergency plans, mitigation measures, evacuations and other contingency responses before the events. It is important that the different forecasting services follow the system from the initial stage to be better prepared. As presented herein, the predictability of $\mathrm{Vb} c y-$ clones is quite good; however, they are very large synoptic systems and damage cannot be completely eliminated, therefore society and operational services must be prepared. These conditions are also demanding for forecasting services, because they require a lot of personnel on duty at the same time for both flood and landslide forecasting.

This study is the result of an inter-institutional and international collaboration across Europe, initiated and promoted in 2016 by the Norwegian Water Resources and Energy Directorate (NVE) in two ways:

a. by creating a network of experts with operational forecasting services towards the prediction of rainfallinduced landslides, who were gathered together during an international workshop in Oslo in October 2016 to establish a forum to exchange of knowledge, challenges and best practices (Devoli, 2017);

b. by promoting collaboration among specific institutions to study specific events; besides the one described herein with ARPA Piemonte, NVE collaborates with the British Geological Survey in order to compare forecasting experiences and to better understand "westerly" synoptic systems that move across the Atlantic in the autumn, causing landslides in UK and Norway (like the storm Desmond on 4 and 5 December 2015).

This study demonstrates the good skill and usefulness of shallow landslide EWSs in cases of large synoptic forcing like $\mathrm{Vb}$ cyclones in different countries. Moreover, it demonstrates that international collaborative efforts among natural hazards prediction centers operating in different countries can be very useful because they can improve knowledge on natural hazards associated with these large synoptic systems, increasing the lead time and the forecasting effectiveness of warning services.

Data availability. All the Norwegian data presented in the document and shown in the figures are publicly accessible, and can be downloaded from http://www.xgeo.no, http://www.senorge.no (Barfod et al., 2013). Landslide data can be downloaded from http://www.skredregistrering.no (NVE, 2018a). The landslide warning presented in Fig. 15 can be visualized at http://www.varsom.no/ (NVE, 2018b).

Competing interests. The authors declare that they have no conflict of interest.

Special issue statement. This article is part of the special issue "Landslide early warning systems: monitoring systems, rainfall thresholds, warning models, performance evaluation and risk perception". It does not belong to a conference.

Edited by: Stefano Luigi Gariano

Reviewed by: Samuele Segoni and two anonymous referees

\section{References}

Awan, N. K. and Formayer, H.: Cutoff low systems and their relevance to large-scale extreme precipitation in the European Alps, Theor. Appl. Climatol., 129, 149-158, https://doi.org/10.1007/s00704-016-1767-0, 2016.

Bardoux, A., Graf, C., Rhyner, J., Kuntner, R., and McArdell, B. W.: A debris-flow alarm system for the Alpine Illgraben 
catchment: design and performance, Nat. Hazards, 49, 517-539, https://doi.org/10.1007/s11069-008-9303-x, 2009.

Barfod, E., Müller, K., Saloranta, T., Andersen, J., Orthe, N. K., Wartianen, A., Humstad, T., Myrabø, S., and Engeset, R.: The expert tool XGEO and its application in the Norwegian Avalanche Forecasting Service, Proceeding International Snow Science Workshop Grenoble, Chamonix MontBlanc, available at: http://arc.lib.montana.edu/snow-science/ objects/ISSW13_paper_P1-13.pdf (last access: 7 May 2018), 2013 (data available at: http://www.xgeo.no, last access: 7 May 2018).

Baum, R. L. and Godt, J. W.: Early warning of rainfall-induced shallow landslides and debris flows in the USA, Landslides, 7, 259272, https://doi.org/10.1007/s10346-009-0177-0, 2010.

Bazin, S.: Guidelines for landslide monitoring and early warning systems in Europe - Design and required technology, Project SafeLand "Living With Landslide Risk in Europe: Assessment, Effects of Global Change, and Risk Management Strategies", Deliverable 4.8, 153 pp., available at: https://www.ngi.no/eng/ Projects/SafeLand (last access: 7 May 2018), 2012.

Bell, R., Cepeda, J., and Devoli, G.: Landslide susceptibility modeling at catchment level for improvement of the landslide early warning system in Norway, Conference Proceedings of the World Landslide Forum, vol. 3, Beijing, China, 2-6 June, 2014.

Beldring, S., Engeland, K., Roald, L. A., Sælthun, N. R., and Voks $\varnothing$, A.: Estimation of parameters in a distributed precipitationrunoff model for Norway, Hydrol. Earth Syst. Sci., 7, 304-316, https://doi.org/10.5194/hess-7-304-2003, 2003.

Biella, G., Gelati, R., Maistrello, M., Mancuso, M., Masiotta, P., and Scarascia, S.: The structure of the upper crust in the AlpsApennines boundary region deduced from refraction seismic data, Tectonophysics, 142, 71-85, https://doi.org/10.1016/00401951(87)90295-2, 1987.

Biella, G., Clari, P., De Franco, R., Gelati, R., Ghibaudo, G., Gnaccolini, M., Lanza, R., Polino, R., Ricci, B., and Rossi, B.: Geometrie crostali al nodo Alpi/Appennino: conseguenze sulla evoluzione cinematica dei bacini neogenici. Atti $76^{\circ}$ congresso della Società Geologica Italiana Riassunti, 192-195, 1992.

Blikra, L. H., Kristensen, L., and Lovisolo, M.: Subsurface monitoring of large rockslides in Norway: a key requirement for early warning, Ital. J. Eng. Geol. Environ., 6, 307-314, https://doi.org/10.4408/IJEGE.2013-06.B-28, 2013.

Boje, S.: Hydrometeorologiske terskel for Jordskredfare på Sørlandet og Østlandet, NVE report 64, 2017, Norwegian Water Resources and Energy Directorate, Oslo, Norway, available at: http://publikasjoner.nve.no/rapport/2017/rapport2017_64.pdf (last access: 7 May 2018), 2017 (in Norwegian).

Boje, S., Colleuille, H., and Devoli, G.: Terskelverdier for utløsning av jordskred i Norge, Oppsummering av hydrometeorlogiske terskelstudier ved NVE i perioden 2009 til 2013, NVENIFS report 43, 2014, Norwegian Water Resources and Energy Directorate, Oslo, Norway, available at: http://publikasjoner.nve. no/rapport/2014/rapport2014_43.pdf (last access: 7 May 2018), 2014 (in Norwegian).

Bucknam, R. C., Coe, J. A., Mota, M., Godt, J. W., Tarr, A. C., Bradley, L. A., Rafferty, S., Hancock, D., Dart, R. L., and Johnson, M. L.: Landslides triggered by Hurricane Mitch in Guatemala - Inventory and Discussion, US Geological Survey Open-File Report 01-0443, 2001.
Calvello, M.: Early warning strategies to cope with landslide risk, Rivista Italiana di Geotecnica, 2, 63-91, https://doi.org/10.19199/2017.2.0557-1405.063, 2017.

Cannon, S. H., Haller, K. M., Ekstrom, I., Schweig, E. S., Devoli, G., Moore, D. W., Rafferty, S. A., and Tarr, A. C.: Landslide Response to Hurricane Mitch Rainfall in Seven Study Areas in Nicaragua, US Geological Survey Open-File Report 01-0412-A Version 1.0, 2002.

Chan, R. K. S, Pang, P. L. R., and Pun, W. K.: Recent developments in the landslip warning system in Hong Kong, in: Proceedings of the 14th Southeast Asian Geotechnical Conference, Balkema, Lisse, the Netherlands, 2003.

Cloutier, C., Agliardi, F., Crosta, G. B., Frattini, P., Froese, C., Jaboyedoff, M., Locat, J., Michoud, C., and Marui, H.: The First International Workshop on Warning Criteria for Active Slides: technical issues, problems and solutions for managing early warning systems, Landslides, 12, 205-212, https://doi.org/10.1007/s10346-014-0530-9, 2015.

Colleuille, H., Boje, S., Devoli, G., Krøgli, I. K., Sund, M., Skaslien, T., Humstad, T., Frekhaug, M., and Wiréhn, P.: Jordskredvarslingen. Nasjonal varslingstjeneste for jord-, sørpe- og flomskredfare NVE report nr. 75, Norwegian Water Resources and Energy Directorate, Oslo, Norway, available at: http://publikasjoner.nve. no/rapport/2017/rapport2017_75.pdf (last access: 7 May 2018), 2017 (in Norwegian).

Cremonini, R. and Bechini, R.: Heavy Rainfall Monitoring by Polarimetric C-Band Weather Radars, Water, 2, 838-848, https://doi.org/10.3390/w2040838 2010.

Cruden, D. M. and Varnes, D. J.: Landslide types and processes. Landslides: Investigation and Mitigation, Special Report 247, Transportation Research Board, Washington, 36-75, 1996.

Davini, P., Bechini, R., Cremonini, R., and Cassardo, C.: Radarbased analysis of convective storms over Northwestern Italy, Atmosphere, 3, 33-58, https://doi.org/10.3390/atmos3010033, 2011.

Decaulne, A. and Sæmundsson P.: Spatial and temporal diversity for debris-flow meteorological control in subarctic oceanic periglacial environments in Iceland, Earth Surf. Process., 32, 1971-1983, https://doi.org/10.1002/esp.1509. 2007.

Devoli, G.: Workshop "Regional early warning systems for rainfalland snowmelt-induced landslides, Need for an international forum?" NVE rapport no. 4, Norwegian Water Resources and Energy Directorate, Oslo, Norway, available at: http:// publikasjoner.nve.no/rapport/2017/rapport2017_04.pdf (last access: 7 May 2018), 2017.

Devoli, G., Kleivane, I., Sund, M., Orthe, N.-K., Ekker R., Johnsen, E., and Colleuille, H.: Landslide early warning system and web tools for real-time scenarios and for distribution of warning messages in Norway, Proceeding IAEG, Torino, Italy, 1519 September 2014, https://doi.org/10.1007/978-3-319-090573_104, 2014.

Devoli, G., Jorandli, L., Engeland, K., and Tallaksen, L. M.: Large-scale synoptic weather types and precipitation responsible for landslides in southern Norway, Proceedings of World Landslide Forum, 4, Ljubljana, Slovenia, 29 May-2 June 2017, https://doi.org/10.1007/978-3-319-53485-5_17, 2017.

Di Biagio, E. and Kjekstad, O.: Early Warning, Instrumentation and Monitoring Landslides, Proc. 2nd in Regional Training Course, Reclaim II, Phuket, Thailand, 18-21, 2007. 
D’Orsi, R., D’Avila, C., Ortigao, J. A. R., Dias, A., Moraes, L., and Santos, M. D.: Rio-Watch: the Rio de Janeiro landslide watch system. In: Proceedings of the 2nd PSL Pan-AM Symposium on Landslides, Rio de Janerio, Brazil, 1, 21-30, 1997.

Falletti, P., Gelati, R., and Rogledi, S.: Oligo-Miocene evolution of Monferrato and Langhe, related to deep structures, in: Rapporti Alpi-Appennino, edited by: Polino, R. and Sacchi R., Accademia Nazionale delle Scienze, Roma, 14, 1-19, 1995.

Fischer, L., Rubensdotter, L., Stalsberg, K., Melchiorre, C., Horton, P., and Jaboyedoff, M.: Debris flow modeling for susceptibility at regional to national scale in Norway, in: Landslides and Engineered Slopes: Protecting Society through Improved Understanding, Taylor and Francis Group, London, 723-729, 2012.

Gariano, S. L. and Guzzetti, F.: Landslides in a changing climate, Earth-Sci. Rev., 162, 227-252, https://doi.org/10.1016/j.earscirev.2016.08.011, 2016.

Gelati, R. and Gnaccolini, M.: Sequenze deposizionali in un bacino episuturale, nella zona di raccordo tra Alpi ed Appennino settentrionale, Atti Ticinensi di Scienze della Terra, 31, 340-350, 1988.

Glade, T. and Nadim, F.: Early warning systems for natural hazards and risks, Nat. Hazards, 70, 1669-1671, https://doi.org/10.1007/s11069-013-1000-8, 2014.

Guzzetti, F., Peruccacci, S., Rossi, M., and Stark, C. P.: The rainfall intensity-duration control of shallow landslides and debris flows: an update, Landslides, 5, 3-17, https://doi.org/10.1007/s10346007-0112-1, 2008.

Haque, U., Blum, P., da Silva, P. F., Andersen, P., Pilz, J., Chalov, S. R., Malet, J.-P., Auflič, M. J., Andres, N., Poyiadji, E., Lamas, P. C., Zhang, W., Peshevski, I., Pétursson, H. G., Kurt, T., Dobrev, N., García-Davalillo, J. C., Halkia, M., Ferri, S., Gaprindashvili, G., Engström, J., and Keellings D.: Fatal landslides in Europe, Landslides,13, 1545-1554, https://doi.org/10.1007/s10346-0160689-3, 2016.

Havenith, H. B., Torgoev, A., Braun, A., Schlögel, R., and Micu, M.: A new classification of earthquake-induced landslide event sizes based on seismotectonic, topographic, climatic and geologic factors, Geoenvironmental Disasters, 3, 1-24, https://doi.org/10.1186/s40677-016-0041-1, 2016.

Huang, M. L. and Hong, J. H.: A Geospatial Service Approach towards the Development of a Debris Flow Earlywarning Systems, Adv. Inf. Sci. Serv. Sci., 2, 107-117, https://doi.org/10.4156/aiss.vol2.issue2.13, 2010.

Hungr, O., Leroueil, S., and Picarelli, L.: The Varnes classification of landslide types, an update, Landslides, 11, 167-194, https://doi.org/10.1007/s10346-013-0436-y, 2014.

Jakob, M., Owen, T., and Simpson, T.: A regional real-time debris-flow warning system for the District of North Vancouver, Canada, Landslides, 9, 165-178, https://doi.org/10.1007/s10346011-0282-8, 2012.

James, P. M.: An objective classification method for Hess and Brezowsky Grosswetterlagen over Europe, Theor. Appl. Climatol., 88, 17-42, https://doi.org/10.1007/s00704-006-0239-3, 2007.

Katsura, S., Kosugi, K., Mizutani, T., Okunaka, S., and Mizuyama, T.: Effects of bedrock groundwater on spatial and temporal variations in soil mantle groundwater in a steep granitic headwater catchment, Water Resour. Res., 44, W09430, https://doi.org/10.1029/2007WR006610, 2008.
Köppen, W.: Die Zugstrassen der barometrischen Minima in Europa und auf dem nordatlantischen Ocean und ihr Einfluss auf Wind und Wetter bei uns, Mitteilungen der Geographischen Gesellschaft in Hamburg, 1, 76-97, 1881.

Krøgli, I. K., Devoli, G., Colleuille, H., Sund, M., Boje, S., and Engen, I. K.: The Norwegian forecasting and warning service for rainfall- and snowmelt-induced landslides, Nat. Hazards Earth Syst. Sci. Discuss., https://doi.org/10.5194/nhess-2017-426, in review, 2017.

Lagomarsino, D., Segoni, S., Fanti, R., and Catani, F.: Updating and tuning a regional scale landslide early warning system, Landslides, 10, 91-97, https://doi.org/10.1007/s10346-0120376-y, 2013.

Lagomarsino, D., Segoni, S., Rosi, A., Rossi, G., Battistini, A., Catani, F., and Casagli, N.: Quantitative comparison between two different methodologies to define rainfall thresholds for landslide forecasting, Nat. Hazards Earth Syst. Sci., 15, 2413-2423, https://doi.org/10.5194/nhess-15-2413-2015, 2015.

Liao, Z., Hong, Y., Wang J., Fukuoka, H., Sassa, K., Karnawati, D., and Fathani, F.: Prototyping an experimental early warning system for rainfall-induced landslides in Indonesia using satellite remote sensing and geospatial datasets, Landslides, 7, 317-324, https://doi.org/10.1007/s10346-010-0219-7, 2010.

Malusa, M. G. and Vezzoli, G.: Interplay between erosion and tectonics in the Western Alps, Terra Nova 18, 104B108, https://doi.org/10.1111/j.1365-3121.2006.00669.x, 2006.

Messmer, M., Gómez-Navarro, J. J., and Raible, C. C.: Climatology of $\mathrm{Vb}$ cyclones, physical mechanisms and their impact on extreme precipitation over Central Europe, Earth Syst. Dynam., 6, 541-553, https://doi.org/10.5194/esd-6-541-2015, 2015.

Meteoweb: Tempeste di sabbia su Malta e in Sicilia, scirocco fino a $120 \mathrm{~km} / \mathrm{h}$ e atmosfera desertica, available at: http://www.meteoweb.eu/2013/05/tempeste-di-sabbia-sumalta-e-in-sicilia-scirocco-fino-a- (last access: 7 May 2018), 2013.

Michoud, C., Bazin, S., Blikra, L. H., Derron, M.-H., and Jaboyedoff, M.: Experiences from site-specific landslide early warning systems, Nat. Hazards Earth Syst. Sci., 13, 2659-2673, https://doi.org/10.5194/nhess-13-2659-2013, 2013.

NVE: Landslide warnings, available at: http://api.nve.no/doc/ jordskredvarsling, last access: 7 May 2018a.

NVE: Norwegian avalanche, flood and landslide hazard warnings, available at: http://www.varsom.no/, last access: 7 May 2018b.

Osanai, N., Shimizu, T., Kuramoto, K., Kojima, S., and Noro, T.: Japanese early-warning for debris flows and slope failures using rainfall indices with Radial Basis Function Network, Landslides, 7, 325-338, https://doi.org/10.1007/s10346-010-0229-5, 2010.

Peel, M. C., Finlayson, B. L., and McMahon, T. A.: Updated world map of the Köppen-Geiger climate classification, Hydrol. Earth Syst. Sci., 11, 1633-1644, https://doi.org/10.5194/hess-11-16332007, 2007.

Petley, D.: Global patterns of loss of life from landslides, Geology 40, 927-930, https://doi.org/10.1130/G33217.1, 2012.

Pfiffner, O. A., Lehner, P., Heitzmann, P., Mueller, S., and Steck, A.: Deep structure of the Alps: results from NRP 20, Birkhäuser Verlag, Basel, https://doi.org/10.1111/j.1365-246X.1997.tb01232.x, 1997.

Piciullo, L., Dahl, M.-P., Devoli, G., Colleuille, H., and Calvello, M.: Adapting the EDuMaP method to test the performance 
of the Norwegian early warning system for weather-induced landslides, Nat. Hazards Earth Syst. Sci., 17, 817-831, https://doi.org/10.5194/nhess-17-817-2017, 2017.

Ponziani, F., Berni, N., Stelluti, M., Zauri, R., Pandolfo, C., Brocca, L., Moramarco, T., Salciarini, D., and Tamagnini, C.: Landwarn: An Operative Early Warning System for Landslides Forecasting Based on Rainfall Thresholds and Soil Moisture, Landslide Science and Practice, Springer-Verlag, Berlin Heidelberg, vol. II, 627-634, https://doi.org/10.1007/978-3-642-31445-2_82, 2013.

Pumo, D., Francipane, A., Lo Conti, F., Arnone, E., Bitonto, P., Viola, F., La Loggia, G., and Noto, L. V.: The SESAMO early warning system for rainfall-triggered landslides, J. Hydroinform., 18, 256-276, https://doi.org/10.2166/hydro.2015.060, 2015.

Roald, L.: Rainfall Floods and Weather Patterns, NVE report 14, Norwegian Water Resources and Energy Directorate, Oslo, Norway, available at: http://publikasjoner.nve.no/oppdragsrapportA/ 2008/oppdragsrapportA2008_14.pdf (last access: 7 May 2018), 2008.

Roald, L.: Flommen på Østlandet i mai 2013, NVE report 21, Norwegian Water Resources and Energy Directorate, Oslo, Norway, available at: http://publikasjoner.nve.no/rapport/2015/ rapport2015_21.pdf, 2015 (in Norwegian).

Rodríguez, C. E., Bommer, J. J., and Chandler, R. J.: Earthquakeinduced landslides: 1980-1997, Soil Dyn. Earthquake Eng., 18, 325-346, https://doi.org/10.1016/S0267-7261(99)00012-3, 1999.

Roure, F., Heitzmann, P., and Polino, R.: Deep structures of the Alps, Société géologique de France, no. 156, 1990.

Roure, F., Bergerat, F., Damotte, B., Munier, J. L., and Polino, R.: The ECORS-CROP Alpine seismic traverse, Société géologique de France, no. 170, 113 pp., 1996.

Segoni, S., Rossi, G., Rosi, A., and Catani, F.: Landslides triggered by rainfall: a semiautomated procedure to define consistent intensity-duration thresholds, Comput. Geosci., 3063, 123-131, https://doi.org/10.1016/j.cageo.2013.10.009, 2014.

Segoni, S., Battistini, A., Rossi, G., Rosi, A., Lagomarsino, D., Catani, F., Moretti, S., and Casagli, N.: Technical Note: An operational landslide early warning system at regional scale based on space-time-variable rainfall thresholds, Nat. Hazards Earth Syst. Sci., 15, 853-861, https://doi.org/10.5194/nhess-15-8532015, 2015.

Segoni, S., Piciullo, L., and Gariano, S. L.: A review of the recent literature on rainfall thresholds for landslide occurrence, Landslides, https://doi.org/10.1007/s10346-018-0966-4, online first, 2018.

Soldati, M., Borgatti, L., Cavallin, A., De Amicis, M., Frigerio, S., Giardino, M., Mortara, G., Pellegrini, G. B., Ravazzi, C., Surian, N., and Tellini, C.: Geomorphological evolution of slopes and climate changes in Northern Italy during the Late Quaternary: spatial and temporal distribution of landslides and landscape sensitivity implications, Geogr. Fis. Din. Quat., 29, 165-183, 2006.

Solli, A. and Nordgulen, Ø.: Bedrock map of Norway and the Caledonides in Sweden and Finland, Scale 1:2000000, Geological Survey of Norway, Trondheim, 2006.

Stähli, M., Sättele, M., Huggel, C., McArdell, B. W., Lehmann, P., Van Herwijnen, A., Berne, A., Schleiss, M., Ferrari, A., Kos, A., Or, D., and Springman, S. M.: Monitoring and prediction in early warning systems for rapid mass movements, Nat. Hazards
Earth Syst. Sci., 15, 905-917, https://doi.org/10.5194/nhess-15905-2015, 2015.

Stoffel, M., Tiranti, D., and Huggel, C.: Climate change impacts on mass movements - case studies from the European Alps, Sci. Total Environ., 493, 1255-1266, https://doi.org/10.1016/j.scitotenv.2014.02.102, 2014.

Thiebes, B., Glade, T., and Bell, R.: Landslide analysis and integrative early warning-local and regional case studies, Proc. 11th International Symposium on Landslides, CRC Press, 1915-1921, 2012.

Tiranti, D. and Rabuffetti, D.: Estimation of rainfall thresholds triggering shallow landslides for an operational warning system implementation, Landslides, 7, 471-48, https://doi.org/10.1007/s10346-010-0198-8, 2010.

Tiranti, D., Rabuffetti, D., Salandin, A., and Tararbra, M.: Development of a new translational and rotational slides prediction model in Langhe hills (north-western Italy) and its application to the 2011 March landslide event, Landslides, 10, 121-138, https://doi.org/10.1007/s10346-012-0319-7, 2013.

Tiranti, D., Cremonini, R., Marco, F., Gaeta, A. R., and Barbero, S.: The DEFENSE (DEbris Flows triggEred by storms - Nowcasting SystEm): an early warning system for torrential processes by radar storm tracking using a Geographic Information System (GIS), Comput. Geosci., 70, 96-109, https://doi.org/10.1016/j.cageo.2014.05.004, 2014.

Tiranti, D., Cremonini, R., Asprea, I., and Marco, F.: Driving Factors for Torrential Mass-Movements Occurrence in the Western Alps, Front. Earth Sci. 4, 16, https://doi.org/10.3389/feart.2016.00016, 2016.

Trigo, R., Zêzere J. L., Rodrigues, M., and Trigo, I.: The Influence of the North Atlantic Oscillation on Rainfall Triggering of Landslides near Lisbon, Nat. Hazards, 36, 331-354, https://doi.org/10.1007/s11069-005-1709-0, 2005.

UN: Sendai Framework for Disaster Risk Reduction, 20152030, UNISDR/GE/2015 - ICLUX EN5000 1st edn., available at: http://www.preventionweb.net/files/43291_ sendaiframeworkfordrren.pdf (last access: 7 May 2018), 2015.

UNISDR: Developing Early Warning Systems: A Key Checklist, available at: http://www.unisdr.org/2006/ppew/info-resources/ ewc3/Checklist-english.pdf (last access: 7 May 2018), 2005.

UNISDR: ISDR: Terminology, available at: http://www.unisdr. org/eng/library/lib-terminology-enghome.htm (last access: 7 May 2018), 2009.

Van Bebber, W. J.: Typische Witterungs-Erscheinungen, Archiv der Deutschen Seewarte und des Marineobservatoriums: Deutsche Seewarte, Hamburg, 5, 1-45, 1882.

Van Bebber, W. J.: Die Zugstrassen der barometrischen Minima nach den Bahnenkarten der deutschen Seewarte für den Zeitraum 1875-1890, Meteorol. Z., 8, 361-366, 1891.

Wood, J. L., Harrison S., Turkington, T. A. R., and Reinhardt L.: Landslides and synoptic weather trends in the European Alps, Clim. Change, 136, 297-308 https://doi.org/10.1007/s10584016-1623-3, 2016.

Zêzere, J. L., Vaz, T., Pereira, S., Oliveira, S. C., Marques, R., and Garcia, R. A. C.: Rainfall thresholds for landslide activity in Portugal: a state of the art, Environ. Earth Sci., 73, 2917-2936, https://doi.org/10.1007/s12665-014-3672-0, 2015. 